\title{
Use of a mobile laboratory to evaluate changes in on-road air pollutants during the Beijing 2008 Summer Olympics
}

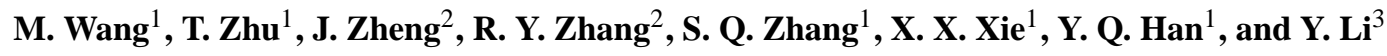 \\ ${ }^{1}$ State Key Laboratory of Environmental Simulation and Pollution Control, College of Environmental Sciences and \\ Engineering, Peking University, Beijing, 100871, China \\ ${ }^{2}$ Department of Atmospheric Sciences, Texas A\&M University, Texas 77843, USA \\ ${ }^{3}$ Chinese Academy of Meteorological Science, Beijing, 100081, China
}

Received: 12 May 2009 - Published in Atmos. Chem. Phys. Discuss.: 5 June 2009

Revised: 11 October 2009 - Accepted: 14 October 2009 - Published: 3 November 2009

\begin{abstract}
China implemented systematic air pollution control measures during the 2008 Beijing Summer Olympics and Paralympics to improve air quality. This study used a versatile mobile laboratory to conduct in situ monitoring of on-road air pollutants along Beijing's Fourth Ring Road on 31 selected days before, during, and after the Olympics air pollution control period. A suite of instruments with response times of less than $30 \mathrm{~s}$ was used to measure temporal and spatial variations in traffic-related air pollutants, including $\mathrm{NO}_{\mathrm{x}}, \mathrm{CO}, \mathrm{PM}_{1.0}$ surface area $\left(\mathrm{S}\left(\mathrm{PM}_{1}\right)\right)$, black carbon $(\mathrm{BC})$, and benzene, toluene, the sum of ethylbenzene, and $m-, p$-, and $o$-xylene (BTEX). During the Olympics (823 August, 2008), on-road air pollutant concentrations decreased significantly, by up to $54 \%$ for $\mathrm{CO}, 41 \%$ for $\mathrm{NO}_{\mathrm{x}}$, $70 \%$ for $\mathrm{SO}_{2}, 66 \%$ for BTEX, $12 \%$ for $\mathrm{BC}$, and $18 \%$ for $S_{\mathrm{PM}_{1}}$, compared with the pre-control period (before 20 July). Concentrations increased again after the control period ended (after 20 September), with average increases of 33\% for $\mathrm{CO}, 42 \%$ for $\mathrm{NO}_{\mathrm{x}}, 60 \%$ for $\mathrm{SO}_{2}, 40 \%$ for BTEX, $26 \%$ for $\mathrm{BC}$, and $37 \%$ for $\mathrm{S}\left(\mathrm{PM}_{1}\right)$, relative to the control period. Variations in pollutants concentrations were correlated with changes in traffic speed and the number and types of vehicles on the road. Throughout the measurement periods, the concentrations of $\mathrm{NO}_{\mathrm{x}}, \mathrm{CO}$, and BTEX varied markedly with the numbers of light- and medium-duty vehicles (LDVs and MDVs, respectively) on the road. Only after 8 August was a noticeable relationship found between $\mathrm{BC}$ and $\mathrm{S}\left(\mathrm{PM}_{1}\right)$ and the number of heavy-duty vehicles (HDVs). Additionally,
\end{abstract}

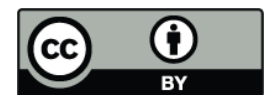

Correspondence to: T. Zhu

(tzhu@pku.edu.cn)
$\mathrm{BC}$ and $\mathrm{S}\left(\mathrm{PM}_{1}\right)$ showed a strong correlation with $\mathrm{SO}_{2}$ before the Olympics, indicating possible industrial sources from local emissions as well as regional transport activities in the Beijing area. Such factors were identified in measurements conducted on 6 August in an area southwest of Beijing. The ratio of benzene to toluene, a good indicator of traffic emissions, shifted suddenly from about 0.26 before the Olympics to approximately 0.48 after the Olympics began. This finding suggests that regulations on traffic volume and restrictions on the use of painting solvents were effective after the Olympics began. This study demonstrated the effectiveness of air pollution control measures and identified local and regional pollution sources within and surrounding the city of Beijing. The findings will be invaluable for emission inventory evaluations and model verifications.

\section{Introduction}

As the host of the 2008 Summer Olympic Games (the Games of the XXIX Olympiad), Beijing drew international attention for its severe air pollution. Since its economic expansion began in the early 1980s, Beijing has become a megacity of more than 17 million residents. High energy demands by both domestic and industrial users have led to ever increasing consumption of fossil fuels in the processes of electricity generation, manufacturing, construction, and transportation. In turn, such activities have produced massive emissions of nitrogen oxides $\left(\mathrm{NO}_{\mathrm{x}}=\mathrm{NO}+\mathrm{NO}_{2}\right)$, carbon monoxide $(\mathrm{CO})$, sulfur dioxide $\left(\mathrm{SO}_{2}\right)$, volatile organic compounds (VOCs), and particulate matter (PM), including black carbon (BC). The air pollution problems in Beijing are characterized by

Published by Copernicus Publications on behalf of the European Geosciences Union. 
poor visibility, resulting from high mass loading of fine PM (Kirchstetter et al., 1999) and high atmospheric oxidation capability, due to photochemical smog formation (Tang, 2004). Recent studies have indicated that both regional and local sources contribute to air pollution events in Beijing, with local sources primarily associated with automobile emissions (Streets et al., 2007). The number of automobiles in Beijing has increased rapidly in recent years, at an annual rate of about 15\% (Hao et al., 2006; Chan et al., 2008). By the year 2020, Beijing is expected to have 5 million automobiles (Han et al., 2008). Automobiles emit substantial amounts of air pollutants into the urban airshed. Liu et al. (2007) estimated that on-road automobiles in Beijing emitted approximately 3 tons of PM, 199 tons of $\mathrm{NO}_{\mathrm{x}}, 192$ tons of VOCs, and 2403 tons of CO daily. Furthermore, chemical massbalance modeling using VOC observations made between 2002 and 2003 showed that automobile exhaust was responsible for $57.7 \%$ of the VOC emissions in Beijing (Liu et al., 2005), while $70 \%$ of the VOCs in summer were traced back to gasoline-engine vehicles and fugitive gasoline vapors (Liu et al., 2005; Song et al., 2008).

To improve air quality and maintain clean air throughout the Olympic Games, systematic long- and short-term emission reduction measures and regulations were implemented before and during the Olympic Games, including relocating heavy polluters (e.g., the Capital Steel Company), introducing strict vehicular emissions standards (equivalent to the Euro 4 standards), reducing on-road private cars by half during the Olympics period through an odd/even plate number rule, and freezing construction activities during the Olympic Games (for details, see Table 2).

For the atmospheric chemistry community, these Olympics air quality measures provided a unique opportunity to study the effects of a set of administrative regulations on air quality in a megacity over a relatively short period. To evaluate the effectiveness of the air pollution measures, an international collaborative field campaign, the "Campaign for Air Quality Research in Beijing and Surrounding Region-2008" (CAREBeijing-2008), was conducted before and during the 2008 Olympics.

As part of CAREBeijing-2008, a mobile research platform was developed and used to provide in situ, rapid-response observations of both the spatial and temporal distributions of traffic emissions. Such data cannot be obtained by currently existing and equipped stationary monitoring sites. Relevant studies of real-time measurements have taken place in Europe (Bukowiecki et al., 2002; Weijers et al., 2004; Pirjola et al., 2006), the United States (Kittelson et al., 2004; Jiang et al., 2005; Westerdahl et al., 2005; Rogers et al., 2006; Zavala et al., 2006; Isakov et al., 2007), and Asia, including Hong Kong (Yao et al., 2006, 2007). However, only preliminary studies had been conducted in Beijing (Westerdahl et al., 2009). Many previous studies focused on ultrafine particle (UFP) measurements along motorways, such as "chase studies" for specific vehicle emission factors (Canagaratna et al., 2004; Herndon et al., 2005). There have been other reports of temporal and spatial analyses in and around certain cities and countries (Bukowiecki et al., 2003; Weijers et al., 2004; Isakov et al., 2007).

In this report, we present in situ, on-road measurements of both trace gases and aerosols in Beijing before, during, and after the 2008 Summer Olympic Games. We examined associations of air pollution with meteorological parameters and the influence of different control measures on air pollutant concentrations. The regional transport of $\mathrm{SO}_{2}$ from the south of Beijing is also discussed. The results of this work demonstrate that a mobile platform is an excellent tool for real-time characterization of on-road air pollution and can provide first-hand evaluations and prompt feedback regarding emission reduction regulations.

\section{Experimental methods}

\subsection{Mobile laboratory platform}

An IVECO Turin $\mathrm{V}$ diesel vehicle $(\mathrm{L}=6.6 \mathrm{~m}, \mathrm{~W}=2.4 \mathrm{~m}$, $\mathrm{H}=2.8 \mathrm{~m}$; payload $=2.7$ metric tons) was selected as the mobile laboratory platform for online instrumentation and for performing on-road measurements (Fig. 1). To ensure the continuous operation of a complete suite of instruments (for measuring gas-phase and aerosols) and to meet the required power consumption of $2.7 \mathrm{~kW}$, two sets of uninterruptible power systems (UPSs), consisting of two series of $12 \mathrm{~V} / 110 \mathrm{Ah}$ lead batteries were installed on the vehicle and could support all the equipment operations without interruption for up to $6 \mathrm{~h}$. In the case of long-range regional measurements, a $6.5 \mathrm{~kW} / 220 \mathrm{~V}$ gasoline-fueled electrical generator could supply power to all the instruments for more than $12 \mathrm{~h}$.

\subsection{Inlet system}

As shown in Fig. 1, four individual sampling inlet systems were constructed to minimize pollutant loss in the inlet and to enhance the sampling efficiency. Three inlets were located separately at the front top of the van, $3.2 \mathrm{~m}$ above the ground to avoid any self-contamination by engine exhaust. One inlet (Fig. 1; position A) was for the gas analyzers $\left(\mathrm{NO}_{\mathrm{x}}, \mathrm{CO}\right.$, $\mathrm{CO}_{2}, \mathrm{SO}_{2}, \mathrm{O}_{3}$ ) and the others (positions $\mathrm{B}, \mathrm{C}$ ) were for the particle instruments and PTR-MS. The gaseous pollutant inlet consisted of $1.27 \mathrm{~cm}$ inner diameter (ID) Teflon tubing and a glass manifold (position F) to reduce chemical reactions on the sampling walls. The total length of the tubes was $6.5 \mathrm{~m}$. The glass manifold included two tubes. Air flow came through the inside tube and then into the outer tube. This design was intended to exclude coarse particles, by gravity, and keep sampling steam from condensing when the temperature difference between inside and outside the van was large. To accelerate the incoming speed of air pollutants and to minimize their absorption on the sampling line walls, a 


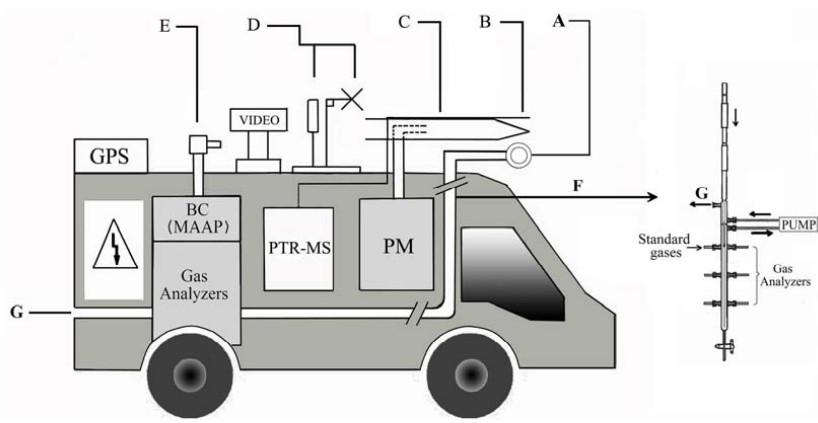

Fig. 1. Overview of mobile laboratory construction in Peking University. (A) gas inlet (B) PTR-MS inlet (C) Aerosol inlet (D) wind speed, wind direction, relative humidity, temperature and pressure sensors (E) BC inlet with $\mathrm{PM}_{2.5}$ cyclone (F) Close up picture of glass manifold tubes $(\mathrm{G})$ outlets of gas analyzers.

16.7 standard liters/min (SLPM) pump was used at the end of the outside glass manifold. These gases were then diverted to each of the gas analyzers through $0.64 \mathrm{~cm}$ ID Teflon tubing by their own 0.5-0.7 SLPM pump.

For particles, an isokinetic sampling system was designed to minimize aerosol aerodynamic losses. When driving at a constant speed of $60 \pm 5 \mathrm{~km} / \mathrm{h}$, airflows containing particles were forced horizontally into a cone-shaped stainless steel tube (position C) with a total length of $60 \mathrm{~cm}$, an inlet with $1.4 \mathrm{~cm} \mathrm{ID}$, and a body ID of $9 \mathrm{~cm}$. The sample flow was decelerated to $0.4 \pm 0.1 \mathrm{~m} / \mathrm{s}$ at laminar flow (Flow Reynolds number $R e<2000$ ). Then, part of the sampling air was isokinetically fed into a vertically positioned stainless steel tube (ID $1.27 \mathrm{~cm}$ ) and into the van, with a constant flow rate of 3.5 SLPM by the particle instruments pumps. The remaining flow was discarded backwards. The horizontal inlet system (position C) had no pump at the back of the 9-cm tube, making it slightly different from the inlet used in a mobile laboratory previous reported (Bukowiecki et al., 2002). To maintain a constant sampling flow rate, the mobile laboratory was kept at a constant speed of $60 \pm 5 \mathrm{~km} / \mathrm{h}$ during on-road measurements, when the road conditions permitted. Particle loss due to gravitational settling, impaction, and diffusion for size D- $1 \mu \mathrm{m}$ and $2.5 \mu \mathrm{m}$ were calculated to be less than $3 \%$ and 9\%, respectively (Hinds, 1999).

The sampling inlet for PTR-MS (position B) was a 0.32cm ID Teflon tube individually attached on the horizontal particle stainless steel tube. The total length was $4.2 \mathrm{~m}$, with an air flow rate of $50 \mathrm{sccm}$. On the rear of the mobile lab, the $\mathrm{BC}$ sampling tube (position $\mathrm{E}$ ), with a length of $0.7 \mathrm{~m}$ and a $\mathrm{PM}_{2.5}$ cyclone inlet of $1.27 \mathrm{~cm}$ ID, was also installed. The air flow rate was 16.7 SLPM and calculated estimates of BC particle loss for size $<2.5 \mu \mathrm{m}$ were less than $2 \%$.

Experimental tests of measured average residence time for gas species between the sampling system inlet and being detected by gas analyzers, particle instruments and BC instru- ment (MAAP) were 18, 5, and 3s, with 9, 25, and $17 \%$ errors, respectively, with respect to calculated values.

\subsection{Instrumentation in the mobile laboratory}

Table 1 provides an overview of all the instruments on board the mobile laboratory, including auxiliary equipment, such as meteorological sensors and a global positioning system (GPS). Instruments deployed on the mobile laboratory were commercial instruments, based on well established technology, with preference for instruments having high time resolution. Gas analyzers from Ecotech (model 9800sA, Australia) were used to measure $\mathrm{NO}_{\mathrm{x}}, \mathrm{CO}$, and $\mathrm{SO}_{2}$, with detection ranges of $0-500 \mathrm{ppb}$ for $\mathrm{NO}_{\mathrm{x}}, 0-9.8 \mathrm{ppm}$ for $\mathrm{CO}$, and 0-221.3 ppb for $\mathrm{SO}_{2}$. The working principle of the Ecotech $\mathrm{NO}-\mathrm{NO}_{2}-\mathrm{NO}_{\mathrm{x}}$ analyzer (model 9841A, Australia) is based on a chemiluminescent technique. The $\mathrm{CO}$ monitor (Ecotech model 9830A) is based on CO absorption of non-dispersive infrared radiation (NDIR) at a wavelength of 4.6 microns. $\mathrm{SO}_{2}$ was measured with an Ecotech model 9850A analyzer, by a fluorescence technique. All the gas analyzers were configured by the manufacturer to record data at $1 \mathrm{~Hz}$. Online measurement data were recorded with an industrial personal computer (IPC).

Aromatic VOCs were measured with a compact protontransfer reaction mass spectrometer (PTR-MS; Ionicon, Austria), as used successfully in Mexico City during the MILAGRO 2006 campaign (Fortner et al., 2009). The working principle of the PTR-MS is based on proton transfer reactions between hydronium ions $\left(\mathrm{H}_{3} \mathrm{O}^{+}\right)$and an analyte with a proton affinity higher than that of water (Lindinger et al., 1998; de Gouw and Warneke, 2007). Benzene, toluene, and the sum of the xylene isomers and ethylbenzene were continuously monitored with the PTR-MS, using the selected ion monitoring mode. Background checks were performed automatically once every hour by passing ambient air through a catalytic converter (de Gouw et al., 2003; Fortner et al., 2009) that could scrub out VOCs without changing the water vapor content. Calibration of the PTR-MS was conducted using US Environmental Protection Agency TO-15 standards before or after each on-road sampling trip. The dynamic range of the calibration was from a few to about a hundred parts per billion by volume (ppbv), to accommodate the wide range of on-road air pollutant concentrations.

$\mathrm{BC}$ was measured with a multi-angle absorption photometer (MAAP; Thermo model 5012, USA), which used a $\mathrm{PM}_{2.5}$ cyclone inlet installed in the middle section of the mobile laboratory. The amount of $\mathrm{BC}$ was quantified by detecting modifications of the radiation field (670-nm visible light source) in the forward and back hemispheres of a glass-fiber filter caused by BC depositions with a time resolution of $1 \mathrm{~min}$ at a flow rate of 16.7 SLPM. The TSI Model 3550 Nanoparticle Surface Area Monitor, with a high time resolution of $3 \mathrm{~s}$, was deployed to measure the corresponding surface area of human lung-depositable particles. Its working principle is 
Table 1. Instrumentation deployed on the PKU mobile laboratory.

\begin{tabular}{|c|c|c|c|}
\hline Parameter & Instrument method/ type & Time resolution & Detection limit \\
\hline \multicolumn{4}{|l|}{ Aerosols } \\
\hline Size distribution $\mathrm{D}=15-673 \mathrm{~nm}$ & Scanning mobility particle sizer (SMPS)/TSI DMA3081, CPC3772 & $2 \mathrm{~min}$ & Not defined \\
\hline Size distribution $\mathrm{D}=0.3-20 \mu \mathrm{m}$ & Optical particle counter(OPC)/Grimm Dust monitor 1.108 & $6 s$ & 1 particle/l \\
\hline Active surface area & Nanoparticle Surface Area Monitor/TSI 3550 & $3 \mathrm{~s}$ & $0.1 \mu \mathrm{m}^{2} / \mathrm{cm}^{3}$ \\
\hline Black carbon & Multi Angle Absorption Photometer(MAAP)/Thermo Model 5012 & $1 \mathrm{~min}$ & $0.1 \mu \mathrm{g} / \mathrm{m}^{3}$ \\
\hline \multicolumn{4}{|c|}{ (1) } \\
\hline $\mathrm{O}_{3}$ & Ozone analyzer(UV absorption)/ECOTECH 9810A & $1 \mathrm{~s}$ & $0.4 \mathrm{ppb}$ \\
\hline $\mathrm{NO}_{\mathrm{x}}$ & $\mathrm{NO}_{\mathrm{x}}$ analyzer(chemiluminescence)/ ECOTECH 9841A & $1 \mathrm{~s}$ & $0.4 \mathrm{ppb}$ \\
\hline $\mathrm{CO}$ & CO analyzer(NDIR Gas Filter Correlation)/ ECOTECH 9830A & $1 \mathrm{~s}$ & $40 \mathrm{ppb}$ \\
\hline $\mathrm{CO}_{2}$ & $\mathrm{CO}_{2}$ analyzer(NDIR Gas Filter Correlation)/ ECOTECH 9820A & $1 \mathrm{~s}$ & $2.0 \mathrm{ppm}$ \\
\hline $\mathrm{SO}_{2}$ & $\mathrm{SO}_{2}$ analyzer(fluorescence)/ ECOTECH 9850A & $1 \mathrm{~s}$ & $0.4 \mathrm{ppb}$ \\
\hline BTEX & Proton Transfer Reaction Mass Spectrometry(PTR-MS)/Ionicon & 30 s/cycle & $<0.3 \mathrm{ppb}$ \\
\hline \multicolumn{4}{|c|}{ 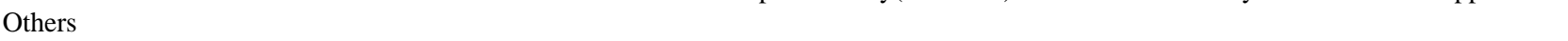 } \\
\hline GPS & Trimble Model GT5011-ST & $1 \mathrm{~s}$ & \\
\hline Temperature & Met One & $<1 \min$ & Not defined \\
\hline Pressure & Met One Model 092 & $<1 \mathrm{~min}$ & $0.1 \mathrm{hPa}$ \\
\hline Relative humidity & Met One Model 083D & $<1 \min$ & Not defined \\
\hline Wind speed/direction & Met One Model 010C/020C & $<1 \mathrm{~min}$ & $0.22 \mathrm{~m} / \mathrm{s}$ \\
\hline
\end{tabular}

based on diffusion charging of sampled particles, followed by detection of the aerosol using an electrometer, with a flow rate of 2.5 SLPM. The output data were recorded on an IBM portable PC.

A freely rotating, high-resolution video camera installed atop the mobile laboratory provided continuous multi-angle views of on-road conditions to identify potential emission sources. A Trimble GPS (model: GT5011-ST) provided precise latitude and longitude data for spatial analysis as well as calculation of moving speed. Both video camera and GPS data were recorded on the IPC.

The Haidian, Chaoyang, and Fengtai meteorological stations of the Chinese Meteorological Administration routinely monitor wind direction (WD) and wind speed (WS). In addition to wind direction and speed, the Peking University Hospital (PKH) station also monitors relative humidity (RH) and temperature $(T)$. Data from these four stations cover the northwest, east, southwest, and central parts of Beijing and were used to represent meteorological conditions along the Fourth Ring Road.

\subsection{Quality assurance and control}

Gas analyzers $\left(\mathrm{NO}_{\mathrm{x}}, \mathrm{CO}, \mathrm{SO}_{2}\right)$ were automatically zeroed and calibrated to $80 \%$ of the detection range with certified calibration standards (500 ppb NO, accuracy 3\%; $9.75 \mathrm{ppm}$ $\mathrm{CO}$, accuracy $3 \%$; and $211.2 \mathrm{ppb} \mathrm{SO}_{2}$, accuracy $3 \%$; all diluted with $\mathrm{N}_{2}$, Beijing Huayuan Gas Chemical Industry Co., Ltd.) before and after each sampling trip. Calibration with five different concentration points $(0 \%, 10 \%, 20 \%, 40 \%$, and $80 \%$ of the detection range) was performed once every five sampling trips. The error of the calibration results, by de- tecting standard gases with respect to the concentrations of standards, was less than $4 \%$. VOC measurement uncertainties were determined from variations in the calibration curve slopes and were usually within $20 \%$ for each VOC species. The BTEX detection limits were less than $0.3 \mathrm{ppbv}$, which was three times the standard deviation of the baseline signals. The MAAP and Nanoparticle Surface Area Monitor were automatically zeroed before the start of each sampling trip. The active surface area concentration calculated from SMPS (Bukowiecki et al., 2002) and the corresponding Nanoparticle Surface Area Monitor concentration agreed within 95\% for these measurements.

Intercomparison was carried out by parking the mobile laboratory on the ground close to the Peking University (PKU) monitoring station, which is approximately $20 \mathrm{~m}$ above ground level. The instruments at the PKU monitoring station for the intercomparison, such as $\mathrm{NO}_{\mathrm{x}}, \mathrm{CO}, \mathrm{SO}_{2}$, and $\mathrm{BC}$, were the same as those in the mobile lab, while a Standard PTR-MS (Ionicon) was used at the PKU monitoring station, whereas a Compact PTR-MS (Ionicon) was in the mobile lab. Calibrations of each instrument were conducted every day by similar methods as those used for the instruments in the mobile lab. Calculated loss efficiencies for $\mathrm{NO}_{\mathrm{x}}, \mathrm{CO}, \mathrm{SO}_{2}, \mathrm{BTEX}$, and $\mathrm{BC}$ while stopping for the intercomparison were less than $1 \%$ (Hinds, 1999). The intercomparison lasted from 24 to 25 August 2008. Differences between gas-pollutant concentrations were found to be within $15 \%$, with correlation coefficients of $0.82,0.89$, and 0.91 for $\mathrm{SO}_{2}, \mathrm{NO}_{\mathrm{x}}$, and $\mathrm{CO}$, respectively. The PTR-MS in the mobile lab and the PTR-MS at the PKU station agreed in their VOC diurnal variation trends. However, the concentration observed by the PTR-MS at the PKU station was only 
about $79 \%$ of that observed by the mobile lab PTR-MS. This difference may be related to the different elevations of the two monitoring locations as well as instrument differences between the respective PTR-MSes at the mobile lab and the PKU station.

\subsection{Air pollution control measures}

Table 2 summarizes various air pollution control measures adopted by the Beijing Municipal Environmental Protection Bureau (EPB). Generally, these measures were classified into before (before 19 July 2008), during (20 July-19 September 2008), and after (after 20 September 2008) the full-scale control periods, according to the magnitude and scale of control measures. The full-scale control period included comprehensive controls on industrial and construction activities, traffic emissions, and gas evaporation. To better clarify the effectiveness of different control measures, especially during the Olympics and Paralympics, we further divided the full-scale control period into four stages, full scale control: before the Olympics (20 July-7 August 2008), during the Olympics (823 August 2008), between the Olympics and Paralympics (24 August-6 September 2008), and during the Paralympics (719 September 2008).

\subsection{Measurement strategy and vehicle traffic speed monitoring}

The Fourth Ring Road (Fig. 2) was selected as the route for each measurement trip because various types of vehicles are allowed on this road and it has no traffic lights and represents typical major road conditions in Beijing. The Fourth Ring Road is $65 \mathrm{~km}$ long and encircles the most urban part of Beijing. We conducted measurements in the afternoon because at this time the Fourth Ring Road normally had no traffic jams, and the mobile laboratory could keep a relatively constant speed during each sampling trip. Each trip started at 15:30 or 16:00 and the Fourth Ring Road circle was completed within approximately $68 \mathrm{~min}$. In total, 31 measurement trips were made, covering the before, during, and post full-scale control periods (Table 2). To clarify the spatial variation of on-road air pollutants and their correlations with other factors, we divided the Fourth Ring Road into north, east, south, and west road sections, which were further equally divided into 16 segments (colored blue and red).

Because of interference by emissions from exhausts immediately in front of the mobile lab, several methods were used to identify and exclude such emission plumes. These included driving the mobile lab at a constant speed and carefully keeping more than $30 \mathrm{~m}$ away from the vehicles in front, checking the wind direction of the incoming wind by meteorological sensors on top of the mobile lab near the sampling inlets, and investigating video camera images when extremely high peak concentrations appeared.

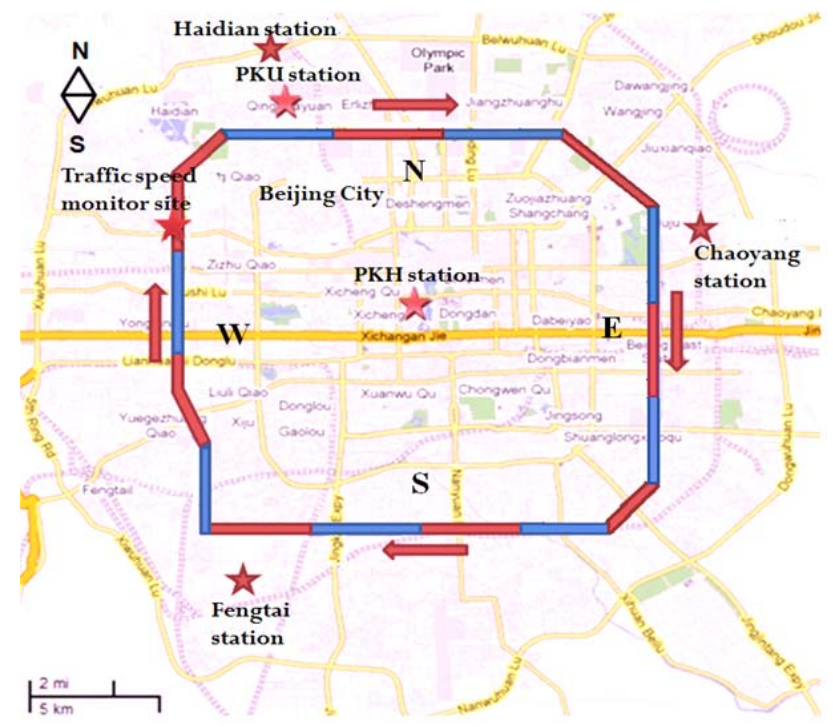

Fig. 2. Map of the city of Beijing. The 4th Ring Road was chosen as the sampling route. For analysis purposes, this route was binned into 16 sections of equal length seen here colored red and blue. The red stars show meteorological stations and places where traffic speed was recorded (Version: Google map 2009).

Self-contamination by exhaust from the engine and generator of mobile laboratory is also an important issue that should be assessed and eliminated from the measurements. In addition to minimizing the influence by measures noted previously, such as using UPS batteries as the power supply and installing the sampling inlet forward, the mobile lab maintained a speed of $60 \pm 5 \mathrm{~km} / \mathrm{h}$, or $17 \mathrm{~m} / \mathrm{s}$, which is much higher than the normal wind speed in Beijing. Thus, during a measurement trip, the exhaust of the vehicle could not reach the front as a result of the wind from the back of the vehicle.

To further examine the level of any self-contamination, the mobile lab was driven on a new highway with almost no other vehicles at $60 \pm 5 \mathrm{~km} / \mathrm{h}$. Pollutants concentrations were measured at background level in this region (e.g., the NO concentration was observed to be less than $3 \mathrm{ppb}$ ), indicating that self-contamination of the platform was negligible.

To continuously monitor traffic speed and vehicle numbers on the Fourth Ring Road, a Sony video camera mounted on Sijiqing Bridge on the west section of the Fourth Ring Road was operated from 17:00 to 18:00 local time for 28 days, corresponding to periods of the research trips. Vehicle types were cataloged into three categories: LDVs, MDVs, and HDVs. 
Table 2. Sampling and starting dates of different air pollution control measures before, during and post 2008 Olympics and Paralympics (compiled from Beijing EPB released information on web page, The 14th control strategy on Beijing air quality, 2008).

\begin{tabular}{|c|c|c|c|c|}
\hline Periods & Detailed Periods ${ }^{a}$ & Starting Dates ${ }^{b}$ & Control measures $^{\mathrm{c}}$ & Sampling dates ${ }^{\mathrm{d}}$ \\
\hline \multirow{3}{*}{$\begin{array}{l}\text { Before full } \\
\text { scale control } \\
\text { (Pre-20 Jul 2008) }\end{array}$} & \multirow{3}{*}{$\begin{array}{l}\text { Before full } \\
\text { scale control } \\
\text { (Pre-20 Jul 2008) }\end{array}$} & 1 Mar 2008 & Introduce new vehicular emission standard, equivalent to Euro 4 & $\begin{array}{l}18 \mathrm{Jul} 2008 \\
19 \mathrm{Jul} 2008\end{array}$ \\
\hline & & $\begin{array}{l}\text { Not } \\
\text { defined }^{\mathrm{e}}\end{array}$ & $\begin{array}{l}\text { Relocating heavy industrial polluters, etc. Shou gang steel factory and other } \\
\text { factories in south area of Beijing; install desulfurization facility in factories } \\
\text { around Beijing } \\
\text { Implementing low fugitive emission facilities at more than } 1000 \text { gas stations }\end{array}$ & \\
\hline & & $\begin{array}{l}23 \text { Jun } \\
2008\end{array}$ & $\begin{array}{l}50 \% \text { of government cars were not allowed to drive. } \\
\text { Diesel and heavy polluting vehicles not allowed to drive in Beijing } \\
\text { Only those vehicles meeting emission standards equivalent to Euro } 2 \text { were } \\
\text { allowed to enter Beijing. }\end{array}$ & \\
\hline \multirow[t]{4}{*}{$\begin{array}{l}\text { Full scale control } \\
\text { (20 Jul 2008- } \\
19 \text { Sep 2008) }\end{array}$} & $\begin{array}{l}\text { Full scale control: } \\
\text { before Olympics } \\
\text { (20 Jul 2008-7 Aug 2008) }\end{array}$ & $20 \mathrm{Jul} 2008$ & $\begin{array}{l}\text { Starting the full scale control } \\
\text { The odd/even plate number rule for traffic control } \\
\text { Stricter control on vehicles entering in Beijing } \\
\text { Reduce or stop production at certain factories surrounding Beijing. }\end{array}$ & $\begin{array}{l}18 \text { Jul } 2008 \\
22 \text { Jul } 2008 \\
28 \text { Jul } 2008 \\
\text { 30 Jul } 2008 \\
4 \text { Aug } 2008\end{array}$ \\
\hline & $\begin{array}{l}\text { Full scale control: } \\
\text { during Olympics } \\
\text { (8-23 Aug 2008) }\end{array}$ & 8 Aug 2008 & $\begin{array}{l}\text { Extra } 20 \% \text { of governmental cars were not allowed to drive. } \\
\text { Stop outdoor construction activities } \\
\text { Temporally close some gas stations } \\
\text { Increase bus fleet and transit frequency }\end{array}$ & $\begin{array}{l}12 \text { Aug } 2008 \\
14 \text { Aug } 2008 \\
16 \text { Aug } 2008 \\
18 \text { Aug } 2008 \\
22 \text { Aug } 2008\end{array}$ \\
\hline & $\begin{array}{l}\text { Full scale control: } \\
\text { Between Olympics and } \\
\text { Paralympics (24 Aug 2008- } \\
6 \text { Sep 2008) }\end{array}$ & & The same as Full scale control: before Olympics & $\begin{array}{l}25 \text { Aug } 2008 \\
27 \text { Aug } 2008 \\
28 \text { Aug } 2008 \\
29 \text { Aug } 2008 \\
4 \text { Sep } 2008 \\
5 \text { Sep } 2008\end{array}$ \\
\hline & $\begin{array}{l}\text { Full scale control: } \\
\text { during Paralympics } \\
\text { (7-19 Sep 2008) }\end{array}$ & & The same as Full scale control: during Olympics & $\begin{array}{l}8 \text { Sep } 2008 \\
9 \text { Sep } 2008 \\
10 \text { Sep } 2008 \\
11 \text { Sep } 2008 \\
18 \text { Sep } 2008 \\
19 \text { Sep } 2008\end{array}$ \\
\hline $\begin{array}{l}\text { Post full } \\
\text { scale control } \\
\text { (After-20 Sep 2008) }\end{array}$ & $\begin{array}{l}\text { Post full } \\
\text { scale control } \\
\text { (After-20 Sep 2008) }\end{array}$ & 20 Sep 2008 & $\begin{array}{l}\text { Lifting of regulations adopted from } 20 \text { July. } \\
\text { Control } 20 \% \text { of private cars based on the last digital of plate number. }\end{array}$ & $\begin{array}{l}22 \text { Sep } 2008 \\
25 \text { Sep } 2008 \\
26 \text { Sep } 2008 \\
28 \text { Sep } 2008 \\
30 \text { Sep } 2008 \\
2 \text { Oct } 2008 \\
6 \text { Oct } 2008\end{array}$ \\
\hline
\end{tabular}

a divided the full scale control period into four periods: full scale control before Olympics, full scale control during Olympics, full scale control between Olympics and Paralympics and full scale control during Paralympics. Therefore, six periods were formed based on different control measures. Details please see Sect. 2.5.

${ }^{\mathrm{b}}$ Showed the starting dates of different control measures on the air pollutants in Beijing and were categorized to the six detailed periods.

${ }^{\mathrm{c}}$ Showed the chief contents of control measures on air pollutants made by Beijing EPB corresponding to different periods.

${ }^{\mathrm{d}}$ Listed the sampling dates with 31 days in total, covering the six detailed periods.

e Means the starting dates were unclear but all of these control measures should be finished before 31 June, 2008.

\section{Results and discussion}

\subsection{Temporal and spatial variations of on-road air pollutants}

As shown in Fig. 3, strong temporal and spatial variations in the concentrations of BTEX, $\mathrm{NO}_{\mathrm{x}}, \mathrm{BC}$, and $\mathrm{PM}_{1}$ surface area $\left(\mathrm{S}\left(\mathrm{PM}_{1}\right)\right)$ were measured from 18 July to 6 October in Beijing. The numbers 1, 2, and 3 represent periods of air pollution control measures: 1, before full-scale control (before
20 July); 2, during full-scale control (20 July-20 September); 3, post-full-scale control (after 20 September). The letters N, E, S, and W represent the north, east, south, and west sections of the Fourth Ring Road, respectively. A constant speed of $60 \pm 5 \mathrm{~km} / \mathrm{h}$ was maintained during each trip, which took roughly $68 \mathrm{~min}$ to complete; each grid therefore represents a 1 -min time window and $1 \mathrm{~km}$ driving distance on the Fourth Ring Road. The blank grids in the figures denote missing data due to technical problems. The sudden changes 


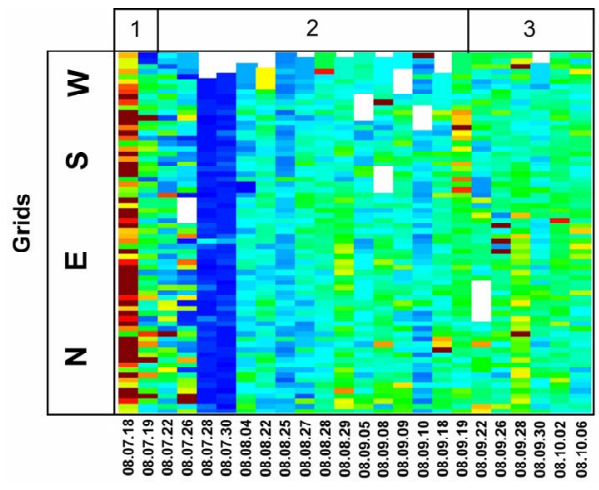

BTEX

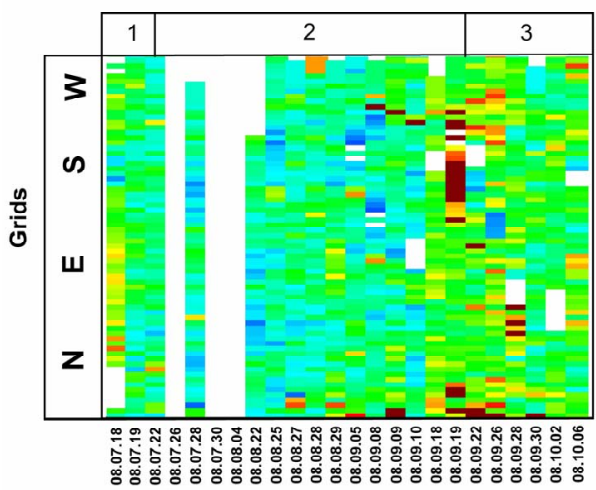

NOx

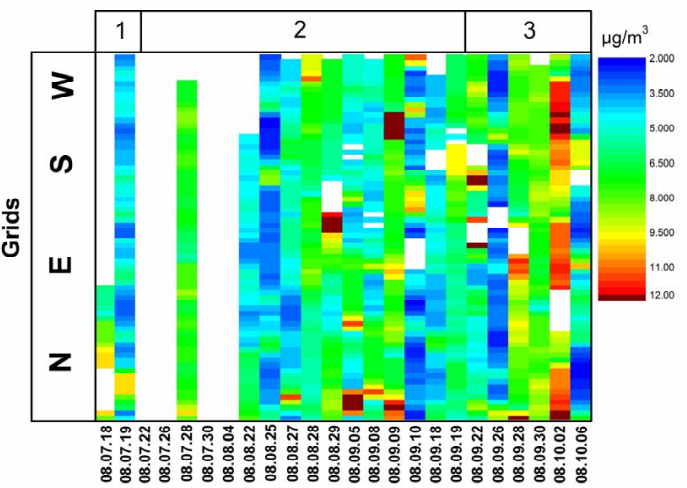

BC

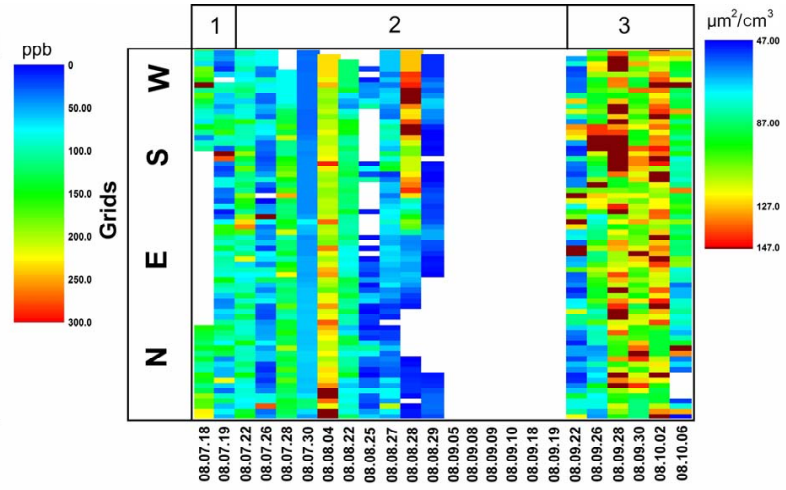

$\mathrm{PM}_{1}$ Surface Area $\left(\mathrm{S}\left(\mathrm{PM}_{1}\right)\right)$

Fig. 3. Temporal and spatial distribution of the concentrations of $B T E X, \mathrm{NO}_{\mathrm{x}}$, and $\mathrm{BC}$, and $\mathrm{PM}_{1}$ surface area $\left(\mathrm{S}\left(\mathrm{PM}_{1}\right)\right)$ along the Fourth Ring Road of Beijing, covering from pre-full scale control to post-full scale control periods. The number 1, 2, 3 represent different periods with regard to traffic control policy changes, 1: before full scale control (before 20 July); 2: during full scale control (20 July-19 September); 3: post full scale control (After 20 September). The letters N, E, S, and W represent the north, east, south, and west sections of the Fourth Ring Road.

in color (mixing ratio) within minutes were associated with air directly emitted from vehicle exhaust.

As shown in Fig. 3, the BTEX concentration was $30 \mathrm{ppb}$ before the full-scale control period; on 22 July, just 2 days after the beginning of the full-scale control, BTEX decreased drastically to about $10.2 \mathrm{ppb}$ and maintained this level until the end of the Olympics, with a level of $7 \mathrm{ppb}$ on 23 August. On 28 and 30 July, BTEX dropped to an average concentration less than $1 \mathrm{ppb}$, mainly due to rain and wind from the north. After the end of the air pollution control period (20 September), BTEX gradually increased and reached a peak level of $15 \mathrm{ppb}$ (28 September). The $\mathrm{NO}_{\mathrm{x}}$ concentration showed a similar trend but increased to a higher level than that of BTEX after the traffic control period ended.

Trends in $\mathrm{S}\left(\mathrm{PM}_{1}\right)$ and $\mathrm{BC}$ concentrations were similar to those of BTEX and $\mathrm{NO}_{\mathrm{x}}$, with the lowest levels observed during the Olympics period. However, after the air pollution control period, both the $\mathrm{PM}_{1}$ surface area and $\mathrm{BC}$ concentration increased by a factor larger than that of BTEX and close to that of $\mathrm{NO}_{\mathrm{x}}$.
To further evaluate the temporal and spatial variation of on-road pollutants before, during, and after the Beijing Olympics, data were examined from the north, east, south, and west sections of the Fourth Ring Road. Figure 4 shows the average concentrations of $\mathrm{NO}_{\mathrm{x}}, \mathrm{CO}, \mathrm{BC}$, and $\mathrm{S}\left(\mathrm{PM}_{1}\right)$ along the four sections during the different air pollution control periods: pre-full-scale control (before 20 July), full-scale control: during the Olympics (8-23 August), and post-fullscale control (after 20 September). The standard deviations indicate the concentration variations in the four segments, as shown in Fig. 2.

Along the four sections, the average concentrations of $\mathrm{NO}_{\mathrm{x}}, \mathrm{CO}, \mathrm{BETX}, \mathrm{SO}_{2}, \mathrm{BC}$, and $\mathrm{S}\left(\mathrm{PM}_{1}\right)$ were all lowest during the Olympics. Among gaseous pollutants and PM, BTEX concentrations showed the largest reduction between the prefull-scale control period and the post-full-scale control period. Concentrations of $\mathrm{NO}_{\mathrm{x}}$ were similar in the pre-fullscale control and post-full-scale control periods, $\mathrm{CO}$ concentrations were lower in the post-full-scale control period than during the pre-full-scale control period, while $\mathrm{SO}_{2}$ and $\mathrm{BC}$ 

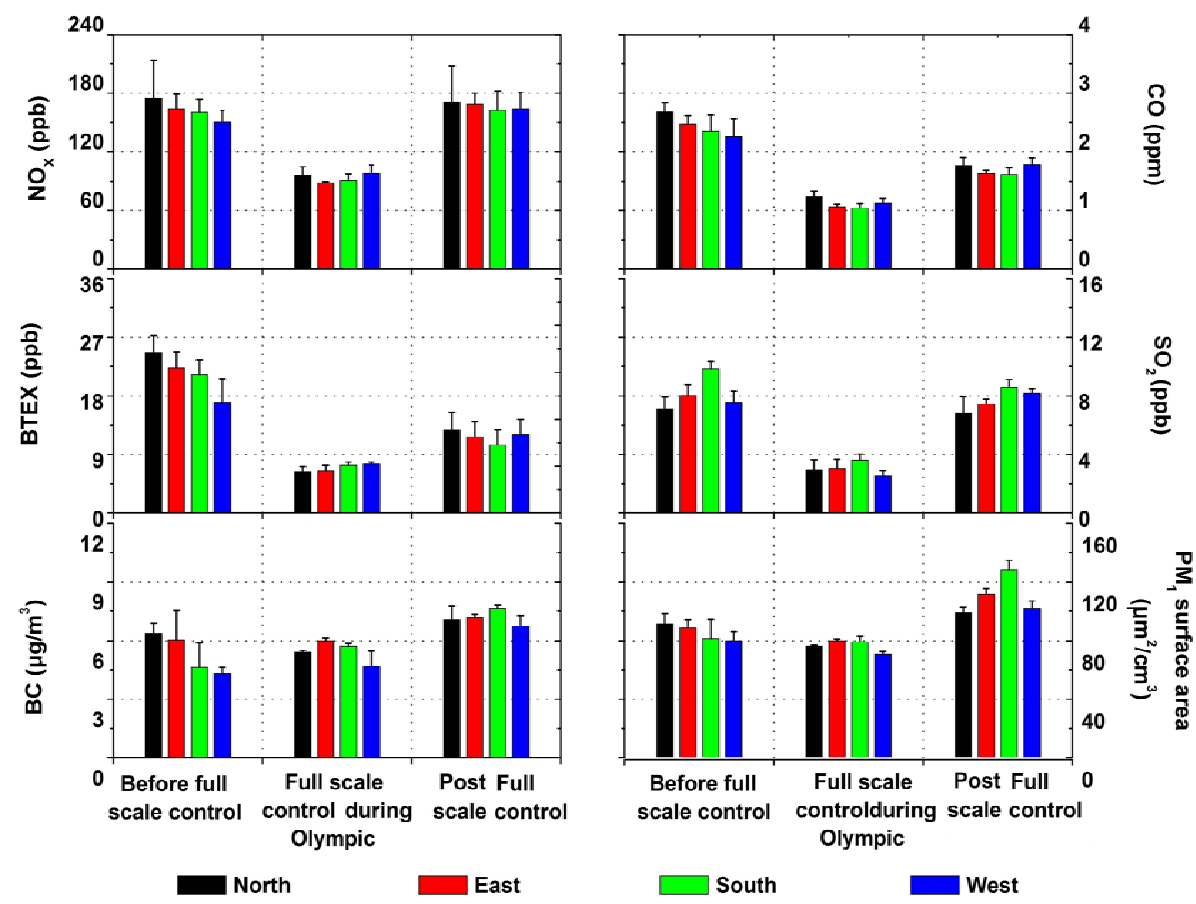

Fig. 4. The spatial variation of selected traffic-related pollutants $\left(\mathrm{NO}_{\mathrm{x}}, \mathrm{CO}, \mathrm{BTEX}, \mathrm{SO}_{2}, \mathrm{BC}\right.$, and $\left.\mathrm{S}\left(\mathrm{PM}_{1}\right)\right)$ on four directions of the Fourth Ring Road (north, east, south and west) during periods of before-full scale control (before 20 July), full scale control during Olympics (8 August-23 August) and post full scale control (After 20 September). The standard deviations represented the concentration differences of those pollutants on four road lines of each side as shown in Fig. 2 during corresponding days of each periods.

concentrations and $\mathrm{S}\left(\mathrm{PM}_{1}\right)$ had slightly higher values in the post-full-scale control period than in the pre-full-scale control period.

During the same periods, no large difference was observed in the average concentrations of on-road air pollutants in the four sections of the Fourth Ring Road, suggesting that the air pollutants were homogeneously distributed in Beijing and that the air pollution controls were effective for the whole city. However, in the pre-full-scale control period, concentrations of $\mathrm{NO}_{\mathrm{x}}, \mathrm{CO}$, and $\mathrm{BTEX}$ and $\mathrm{S}\left(\mathrm{PM}_{1}\right)$ showed similar spatial distributions, with the highest values in the north section, followed by the east, south, and west sections. This result probably reflects the impact of the prevailing wind direction on the dispersion of air pollutants; during the sampling trips, winds were primarily from the south and southwest. Thus, the north and east sections would have been downwind of Beijing and influenced by vehicular emissions from the city, while the south and west sections would have been upwind. During and after the Olympics, this spatial distribution pattern changed, probably due to implementation of the air pollution reduction measures within Beijing during the Olympics as well as a change in wind patterns after the Olympics. The exception of $\mathrm{SO}_{2}$ in the spatial variation likely reflects the long-distance transport of $\mathrm{SO}_{2}$ from other areas, because no major $\mathrm{SO}_{2}$ emission source exists within the city of Beijing.

\subsection{Influence of meteorological conditions on air pollutants}

Given that meteorological conditions also influence the concentrations of gaseous pollutants and PM, we also assessed the influence of wind speed, wind direction, relative humidity, and temperature on air pollutant concentrations. Figure 5 shows a rose plot of wind speed and direction in Beijing from 15:30 to 17:00 on the days of our sampling trips. These results confirm that wind patterns were consistent at different stations in Beijing, with prevailing winds from the south, southwest, and northeast. With low wind speed $\left(<2 \mathrm{~m} \mathrm{~s}^{-1}\right)$, more fluctuation in wind direction was observed.

Table 3 shows the correlation coefficients between the concentrations of air pollutants averaged over each road segment and the meteorological parameters (wind speed, relative humidity and temperature) measured at the PKH station throughout the campaign. We used PKH data, because this station is located at the center of Beijing. Generally, wind speed and temperature showed slightly negative correlations with the concentrations of all the examined pollutants. Also, the concentrations of air pollutants showed slight positive correlations with relative humidity. Although no pronounced correlation was found within the whole measurement period, certain meteorological conditions unfavorable for pollutant dispersion may have led to high levels of air pollution. For example, on 4 August, $\mathrm{SO}_{2}$ and $\mathrm{BC}$ concentra- 
Table 3. Correlations coefficients $(r)$ between air pollutants and wind speed, temperature, and relative humidity.

\begin{tabular}{lrrrrrrrr}
\hline & $\mathrm{CO}$ & $\mathrm{NO}_{\mathrm{x}}$ & $\mathrm{SO}_{2}$ & Benzene & Toluene & $\mathrm{X}+\mathrm{E}$ & $\mathrm{BC}$ & $\mathrm{S}\left(\mathrm{PM}_{1}\right)^{\mathrm{a}}$ \\
& $N=193$ & $N=201$ & $N=203$ & $N=218$ & $N=218$ & $N=218$ & $N=182$ & $N=159$ \\
\hline Wind speed & -0.03 & -0.05 & -0.06 & -0.11 & -0.11 & -0.11 & -0.05 & $0.21^{*}$ \\
Temperature & 0.07 & $-0.44^{* *}$ & -0.01 & $-0.28^{*}$ & $-0.35^{* *}$ & $-0.35^{* *}$ & $-0.30^{* *}$ & $-0.31^{* *}$ \\
Relative humidity & $0.39^{* *}$ & -0.06 & $0.41^{* *}$ & $0.36^{* *}$ & 0.11 & $0.19^{*}$ & $0.36^{* *}$ & 0.04 \\
\hline
\end{tabular}

* Correlation is significant at the 0.05 level (2-tailed).

** Correlation is significant at the 0.01 level (2-tailed).

a $\mathrm{S}\left(\mathrm{PM}_{1}\right): \mathrm{PM}_{1}$ surface area.

tions and $\mathrm{S}\left(\mathrm{PM}_{1}\right)$ increased rapidly to $17.3 \mathrm{ppb}, 7.27 \mu \mathrm{g} / \mathrm{m}^{3}$ and $122.5 \mu \mathrm{m}^{2} / \mathrm{cm}^{3}$, respectively, concurrent with high relative humidity and low wind speed.

Figure 6 shows the correlations between benzene concentrations averaged for each of sixteen segments and corresponding relative humidity and temperature in the pre-, during, and post-full-scale control periods. By selecting the high-frequency distributions of relative humidity and temperature among the whole data, the ranges in relative humidity and temperature were chosen as $35-62 \%$ and $25-35^{\circ} \mathrm{C}$, respectively. The benzene concentrations had weak positive correlations with relative humidity and negative correlations with temperature. However, benzene concentrations varied in different periods within similar, short relative humidity and temperature ranges. Before the Olympics, benzene varied from 4 to $6 \mathrm{ppb}$ within a relative humidity range of $50-60 \%$ and temperature range of $30-32^{\circ} \mathrm{C}$. This was much higher than the values of $0-3 \mathrm{ppb}$ during and after the Olympics within the same relative humidity and temperature ranges. This large difference clearly indicates that the emission control measures were very effective in reducing on-road concentrations of benzene.

\subsection{Effectiveness of the measures on reducing air pollutants}

\subsubsection{Traffic-related air pollutants}

Both $\mathrm{CO}$ and $\mathrm{NO}_{\mathrm{x}}$ are commonly used as traffic emission indicators. Table 4 shows significant positive correlations between the concentrations (averaged over each of the 16 segments of the Fourth Ring Road throughout the whole campaign) of $\mathrm{CO}$ and BTEX and of $\mathrm{NO}_{\mathrm{x}}$ and BTEX, which ranged from 0.66 to 0.76 and 0.60 to 0.70 , respectively. Benzene is a marker of volatile aromatic hydrocarbons in regions of intensive traffic (Khoder, 2007). It displayed strong correlations $(r>0.86)$ with other BTEX species in our study, indicating that vehicular sources were responsible for most of the BTEX. Thus, it was concluded that most of the $\mathrm{CO}, \mathrm{NO}_{\mathrm{x}}$, and BTEX measured in this study were likely from motor vehicle emissions, which previous studies have estimated as accounting for $74 \%$ of the $\mathrm{NO}_{\mathrm{x}}$ and $57.7 \%$ of VOCs emitted in
Beijing (Hao et al., 2005; Liu et al., 2005). Given that emissions from LDVs with gasoline engines have been identified as the major portion of the total vehicular emissions in Beijing (Hao et al., 2005; Song et al., 2007), concentrations of on-road air pollutants (e.g., $\mathrm{CO}, \mathrm{NO}_{\mathrm{x}}$, BTEX species) should be well correlated with the number of LDVs on the road, as will be discussed in a later section.

$\mathrm{BC}$ is emitted by combustion sources, such as vehicles, power plants, and biomass burning. $\mathrm{S}\left(\mathrm{PM}_{1}\right)$ served as an indicator of fine particles in our study. A good association was shown between $\mathrm{S}\left(\mathrm{PM}_{1}\right)$ and $\mathrm{BC}(r=0.7$; Table 4$)$, but both correlated weakly with $\mathrm{CO}$ and $\mathrm{NO}_{\mathrm{x}}(r<0.43$; Table 4$)$. The correlation between $\mathrm{S}\left(\mathrm{PM}_{1}\right)$ and $\mathrm{BC}$ indicated that on-road fine particles and $\mathrm{BC}$ came from similar sources. The weak correlation with $\mathrm{CO}$ and $\mathrm{NO}_{\mathrm{x}}$ suggested that $\mathrm{BC}$ and $\mathrm{S}\left(\mathrm{PM}_{1}\right)$ in Beijing might come from sources other than LDVs. Because industrial activities were curtailed and biomass combustion was strictly prohibited during the Olympics, we believe that $\mathrm{BC}$ and $\mathrm{S}\left(\mathrm{PM}_{1}\right)$ could be generated by HDVs with diesel engines, as has been reported in other research (Fruin et al., 2004; de Castro et al., 2008), although HDV exhaust does not constitute a major portion of overall traffic exhaust in Beijing.

\subsubsection{Association between on-road air pollutants and number of vehicles}

Different air pollution control measures were implemented at different stages of the Olympics. To evaluate the effects of various control measures on reducing air pollution in Beijing (Table 2), we divided the data set into the following six periods covering both the Olympics and Paralympics periods: 1, before full-scale control (before 20 July); 2, full-scale control before the Olympics (20 July-7 August 2008); 3, fullscale control during the Olympics (8-23 August 2008); 4, full-scale control between the Olympics and the Paralympics (24 August-6 September 2008); 5, full-scale control during the Paralympics (7-19 September 2008); 6, post-full-scale control (after 20 September 2008).

Figure $7 \mathrm{a}$ and $\mathrm{b}$ shows the average concentrations of $\mathrm{NO}_{\mathrm{x}}$, $\mathrm{CO}$, and BTEX in these different control periods, and the concurrent numbers of LDVs and MDVs per hour; Fig. 7c 
Table 4. Correlations coefficients ( $r$ ) between on-road air pollutants measured pre (before 20 July), during (20 July-19 September), and post (After 20 September) full-scale control periods.

\begin{tabular}{lrrrrrrrr}
\hline & $\mathrm{CO}$ & $\mathrm{NO}_{\mathrm{x}}$ & $\mathrm{SO}_{2}$ & Benzene & Toluene & $\mathrm{X}+\mathrm{E}$ & $\mathrm{S}_{\left(\mathrm{PM}_{1}\right)^{\mathrm{a}}}$ & $\mathrm{BC}$ \\
& $N=153$ & $N=131$ & $N=143$ & $N=149$ & $N=149$ & $N=149$ & $N=101$ & $N=121$ \\
\hline $\mathrm{CO}$ & 1 & & & & & & & \\
$\mathrm{NO}_{\mathrm{x}}$ & $0.70^{* *}$ & 1 & & & & & & \\
$\mathrm{SO}_{2}$ & $0.65^{* *}$ & 0.18 & 1 & & & & & \\
$\mathrm{Benzene}$ & $0.66^{* *}$ & $0.60^{* *}$ & $0.34^{* *}$ & 1 & & & & \\
Toluene & $0.75^{* *}$ & $0.68^{* *}$ & $0.23^{* *}$ & $0.88^{* *}$ & 1 & & & \\
$\mathrm{X}+\mathrm{E}$ & $0.76^{* *}$ & $0.67^{* *}$ & $0.20^{*}$ & $0.86^{* *}$ & $0.93^{* *}$ & 1 & & \\
$\mathrm{~S}\left(\mathrm{PM}_{1}\right)^{\mathrm{a}}$ & $0.35^{* *}$ & $0.30^{*}$ & $0.45^{* *}$ & $0.25^{*}$ & 0.19 & 0.18 & 1 & \\
$\mathrm{BC}$ & $0.43^{* *}$ & $0.31^{* *}$ & $0.54^{* *}$ & $0.34^{* *}$ & $0.20^{*}$ & $0.22^{*}$ & $0.70^{* *}$ & 1 \\
\hline
\end{tabular}

* Correlation is significant at the 0.05 level (2-tailed).

** Correlation is significant at the 0.01 level (2-tailed).

${ }^{\text {a }} \mathrm{S}\left(\mathrm{PM}_{1}\right): \mathrm{PM}_{1}$ surface area.

shows the $\mathrm{BC}$ concentration and $\mathrm{S}\left(\mathrm{PM}_{1}\right)$ with the number of HDVs per hour. The standard deviations represent the concentration variation of those pollutants during each sampling trip within corresponding periods.

Pollutant concentrations varied widely by period according to policy alterations and appeared to be strongly influenced by traffic density. Before full-scale traffic control (before 20 July), $\mathrm{NO}_{\mathrm{x}}, \mathrm{CO}$, and BTEX concentrations had similar patterns, reaching peak values of $110.8 \pm 30.0 \mathrm{ppb}$ for $\mathrm{NO}_{\mathrm{x}}, 2.4 \pm 0.7 \mathrm{ppm}$ for $\mathrm{CO}, 3.4 \pm 3.0 \mathrm{ppb}$ for benzene, $7.4 \pm 3.4 \mathrm{ppb}$ for toluene, and $10.4 \pm 4.7 \mathrm{ppb}$ for $\mathrm{X}+\mathrm{E}$. Under the strictest vehicle restrictions during the Olympics (8-23 August), each of these species reached its lowest concentrations recorded during this study. After the Olympics, the average values of these species again increased. These trends correspond to those in the numbers of LDVs and MDVs per hour on the Fourth Ring Road. This result is consistent with the assumption that gasoline-fueled LDVs and MDVs are the main sources of $\mathrm{NO}_{\mathrm{x}}, \mathrm{CO}$, and BTEX in Beijing. Apparently, controlling the number of LDVs and MDVs on the road was very effective in reducing $\mathrm{NO}_{\mathrm{x}}, \mathrm{CO}$, and BTEX concentrations.

Furthermore, during the Olympics and the periods thereafter, the $\mathrm{BC}$ concentration and $\mathrm{S}\left(\mathrm{PM}_{1}\right)$ showed increasing trends similar to those in the number of HDVs. This finding suggests that diesel-powered HDVs may be major sources of on-road BC and fine particles. However, before the Olympics period, the changes in $\mathrm{BC}$ concentration and $\mathrm{S}\left(\mathrm{PM}_{1}\right)$ did not closely follow the change in HDV number, indicating that before the Olympics, other emission sources, such as industrial activities and biomass burning, also contributed to on-road fine particles and BC.

\subsection{Sources of $\mathrm{SO}_{2}, \mathrm{BC}$, and $\mathrm{S}\left(\mathrm{PM}_{1}\right)$}

$\mathrm{BC}$ and $\mathrm{S}\left(\mathrm{PM}_{1}\right)$ have weak correlations with $\mathrm{CO}$ and $\mathrm{NO}_{\mathrm{x}}$, with correlation coefficients ( $\mathrm{r}$ values $<0.43$; Table 4 ), while their correlation with $\mathrm{SO}_{2}$ was stronger ( $\mathrm{r}$ values $>0.45$ ). This suggests that regional transport might also play a role in contributing to on-road fine particles. Because $\mathrm{SO}_{2}$ was strictly regulated in Beijing, the likely sources of this pollutant were outside the city.

Further information about the sources of fine particles is shown in Fig. 7c, which shows that BC concentration and $\mathrm{S}\left(\mathrm{PM}_{1}\right)$ correlated with the number of HDVs differently in the periods before and after 8 August. After 8 August, both $\mathrm{BC}$ concentration and $\mathrm{S}\left(\mathrm{PM}_{1}\right)$ followed the trend of HDVs numbers well. This indicates that BC and on-road fine particles came from different sources in these two periods. Although $\mathrm{BC}$ data were recorded on only one day during the period of 20 July to 7 August, the same type of instrument at a ground-based station displayed a trend of $\mathrm{BC}$ concentrations similar to that illustrated in Fig. 7c.

To identify the underlying causes of the observed patterns of $\mathrm{BC}$ and $\mathrm{S}\left(\mathrm{PM}_{1}\right)$, we divided the periods into before and after 8 August to examine correlations between $\mathrm{BC}$ and $\mathrm{S}\left(\mathrm{PM}_{1}\right)$ with $\mathrm{NO}_{\mathrm{x}}, \mathrm{CO}, \mathrm{BTEX}$, and $\mathrm{SO}_{2}$. As shown in Table 5 , before 8 August, $\mathrm{BC}$ and $\mathrm{S}\left(\mathrm{PM}_{1}\right)$ had weak correlations with BTEX $(r<0.23), \mathrm{NO}_{\mathrm{x}}(r<0.31)$, and $\mathrm{CO}$ $(r<0.41)$, but strong associations with $\mathrm{SO}_{2}(r>0.86)$. However, after 8 August, higher correlations of $\mathrm{BC}$ and $\mathrm{S}\left(\mathrm{PM}_{1}\right)$ to BTEX $(r>0.52), \mathrm{NO}_{\mathrm{X}}(r>0.60)$, and $\mathrm{CO}(r>0.63)$ were observed, while the correlation coefficient of $\mathrm{SO}_{2}$ to $\mathrm{BC}$ and $\mathrm{S}\left(\mathrm{PM}_{1}\right)$ declined, to less than 0.52. This difference indicates that, before 8 August, $\mathrm{BC}$, fine particles, and $\mathrm{SO}_{2}$ were very likely from similar sources, most likely from emissions by industrial and power plant sources; after 8 August, under stricter regulations, the main sources that emitted $\mathrm{BC}$, fine particles, and $\mathrm{SO}_{2}$ were effectively controlled, while the 

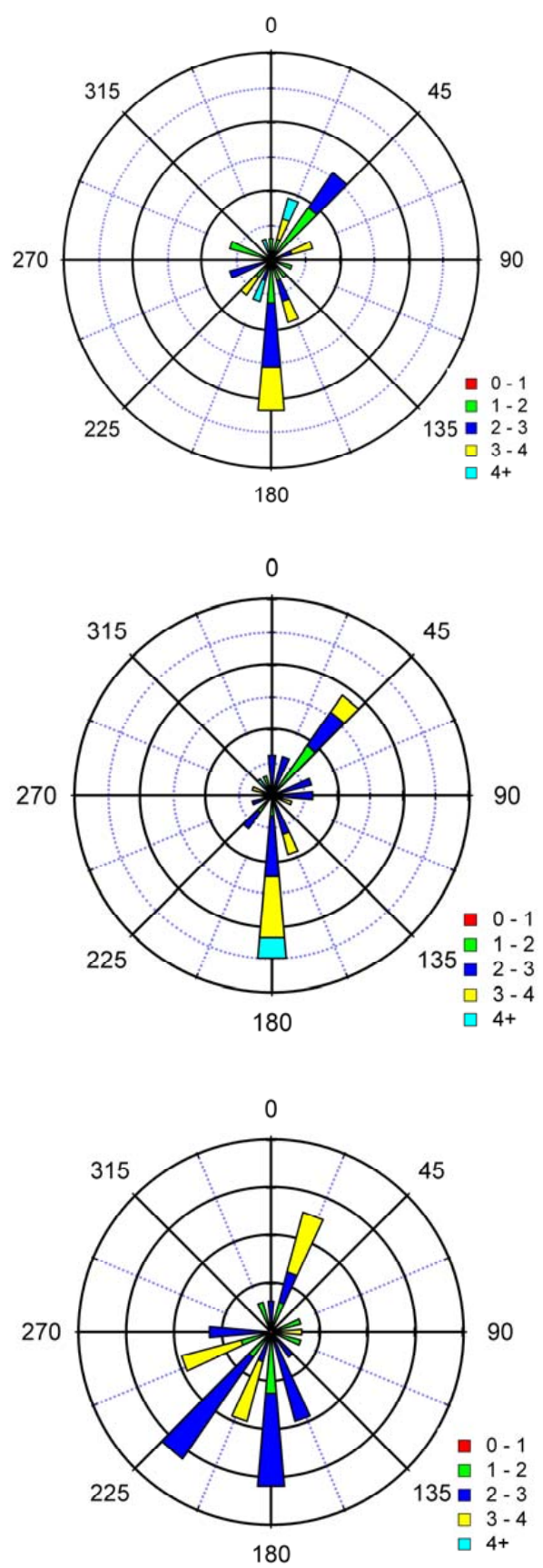

Fig. 5. Rose plots of wind measurements at (a) Haidian (NW), (b) Chaoyang (E), and (c) Fengtai (SW) meteorological stations during the period of on-road measurements.

strong correlations of $\mathrm{NO}_{\mathrm{x}}, \mathrm{CO}$, and BTEX between $\mathrm{BC}$ and $\mathrm{S}\left(\mathrm{PM}_{1}\right)$ suggest that $\mathrm{BC}$ and $\mathrm{S}\left(\mathrm{PM}_{1}\right)$ were primarily from vehicular sources, most likely HDVs with diesel-fueled engines.
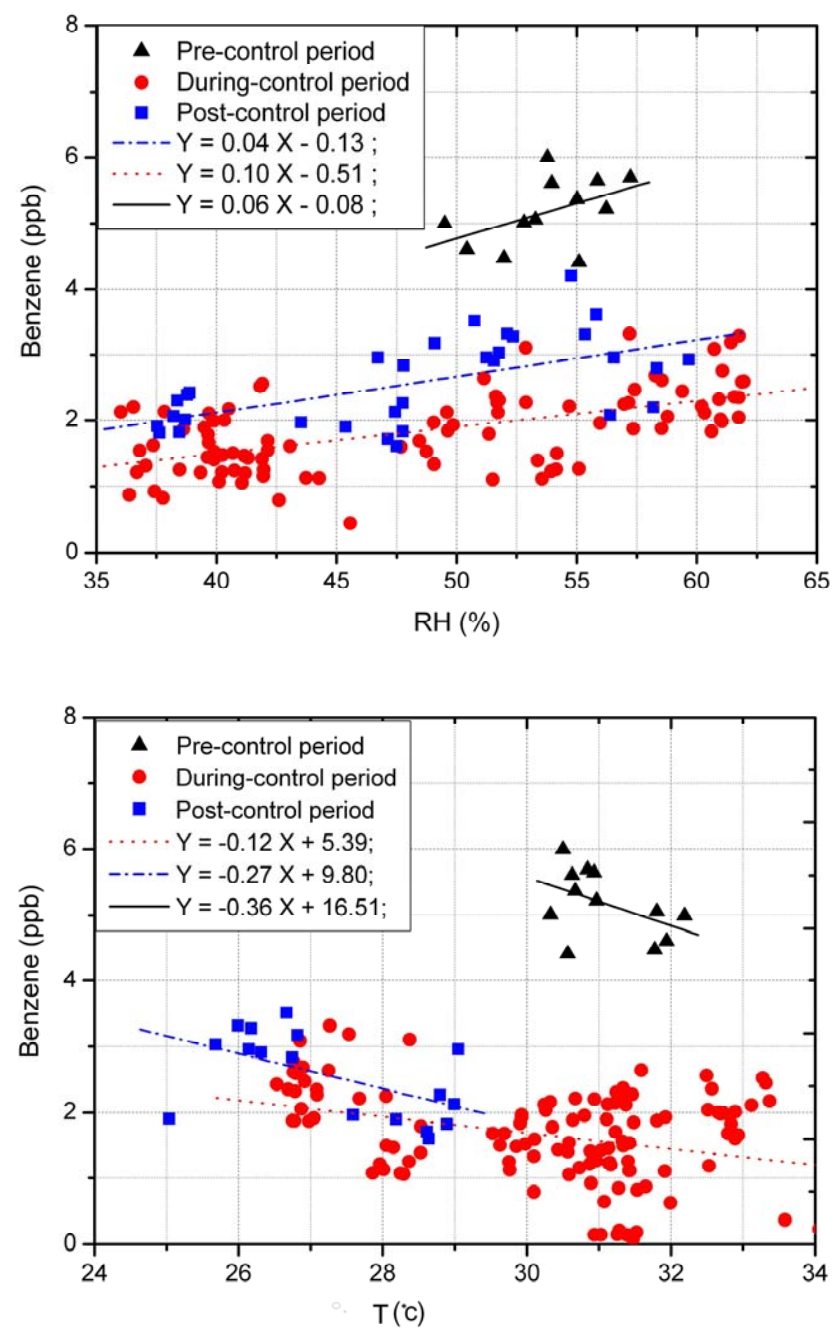

Fig. 6. Correlations between benzene and RH, $T$ during the pre (before 20 July), during (20 July-19 September), and post (After 20 September) full scale control periods. Each plot represented benzene concentrations of each road lines as shown in Fig. 2 corresponding to $T$ and RH.

\subsection{BTEX: vehicular emissions versus paints and solvents}

The benzene/toluene ratio $(\mathrm{B} / \mathrm{T})$ is a key indicator of aromatics originating predominantly from vehicle emissions (Beauchamp et al., 2004; Hoque et al., 2008). This ratio is useful for estimating the photochemical age of an air mass (Khoder, 2007) and is, thus, a good indicator of different emission sources. The atmospheric lifetimes for benzene and toluene have been estimated as 9.4 and 1.9 days, respectively, due to their reactions with $\mathrm{OH}$ (Atkinson, 2000). The B/T is normally the same in urban areas, ranging from 0.25 to 0.5 , and usually around 0.5 when vehicle emissions are the primary sources (Perry and Gee, 1995; Brocco et al., 1997; Barletta et al., 2005). The rapid response of the PTR-MS 


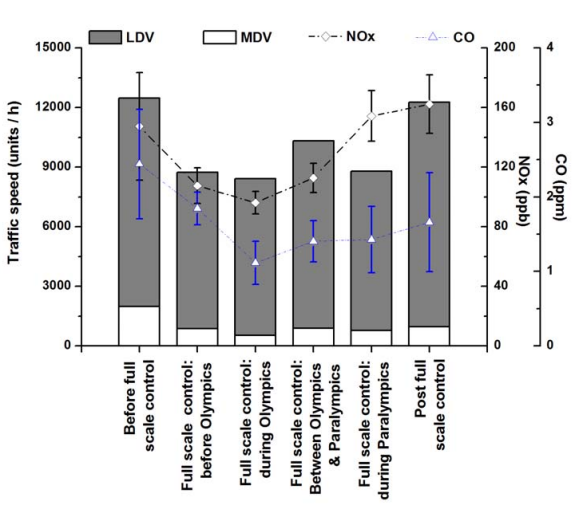

(a)

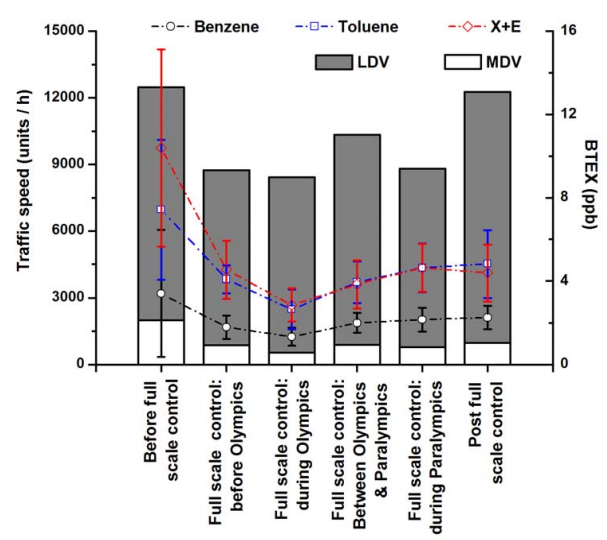

(b)

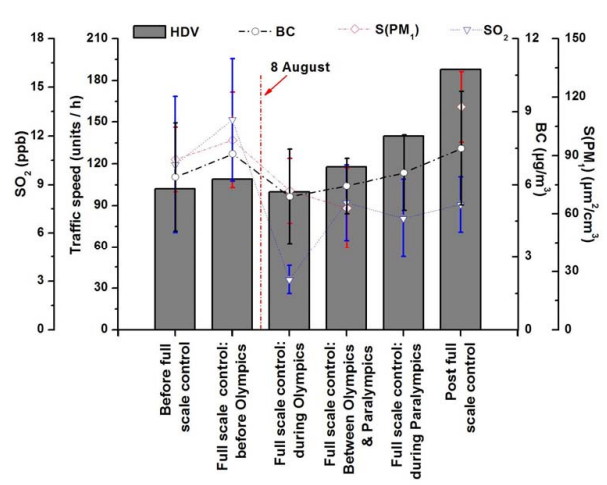

(c)

Fig. 7. The traffic-related pollutants ((a) $\mathrm{NO}_{\mathrm{x}}, \mathrm{CO}$, (b) BTEX, (c) $\mathrm{BC}$ and $\mathrm{S}\left(\mathrm{PM}_{1}\right)$ ) separated into six periods based on policy changes; Before full scale control (before-20 July), Full scale control: before Olympics(20 July-7 August), Full scale control: during Olympics( 8 August-23 August), Full scale control: between Olympics and Paralympics (24 August-6 September), Full scale control: during Paralympics (7 September-19 September), Post full scale control (after-20 September) and corresponding vehicle numbers. The standard deviations represented the concentration differences of those pollutants during each cruise among each of corresponding periods.

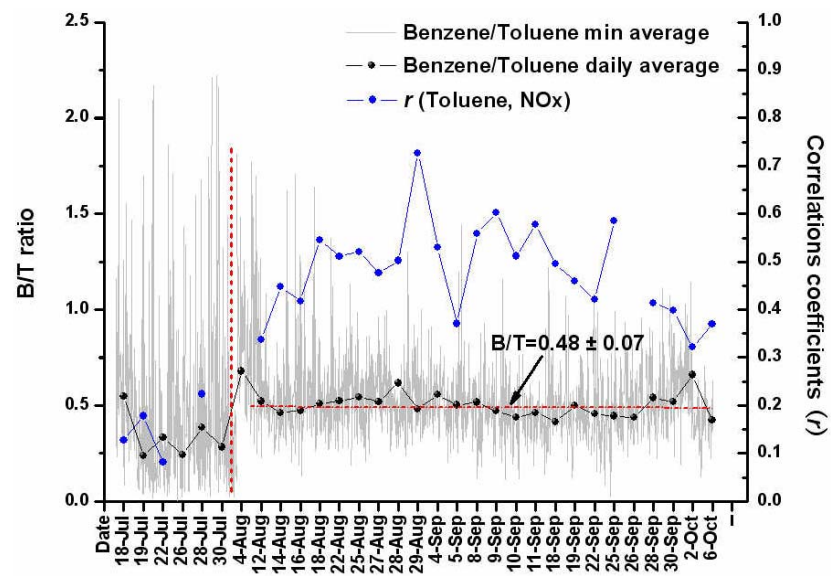

Fig. 8. The ratio of benzene to toluene for all cruises. The light grey line represents minute averages. The black line with symbols shows daily averages. The red line shows the average ratio as calculated for the stable period (from 4 August to 6 October). The blue symbol line shows daily correlations $(r)$ between toluene and $\mathrm{NO}_{\mathrm{x}}$. The red vertical dashed line separates the dates at 4 August.

allowed us to observe real-time variation in the $\mathrm{B} / \mathrm{T}$ ratio (Fig. 8). The large fluctuation in the B/T ratio in Fig. 8 is due to the high time resolution of the PTR-MS ( $30 \mathrm{~s})$, which allows it to register the passage of different emission plumes, reflecting traffic-related factors, such as traffic density, vehicle types, fuel composition, and fresh exhausts from vehicles directly in front of the mobile laboratory.

From 19 July to 3 August, B/T values were low and highly variable, with an average value of $0.26 \pm 0.06$. In contrast, higher $\mathrm{B} / \mathrm{T}$ values with less fluctuation were observed after 12 August, when the average value was $0.48 \pm 0.07$. Benzene and toluene are emitted in vehicle exhaust and gasoline evaporation, while toluene is also released from the use of solvents (e.g., painting, printing, dry cleaning activities; $\mathrm{Na}$ et al., 2003), the evaporation of which depends closely on the ambient temperature (Schnitzhofer et al., 2008). This suggests that the lower B/T from 19 July to 3 August may have been caused by the heavy use of painting solvents for decorating projects in preparation for the Olympics as well as fugitive gasoline emissions containing more toluene than benzene. However, after 12 August, with decorations complete and rigorous controls on solvent usage in place, toluene emissions from paints and solvents became less important than those from vehicular sources, and the $\mathrm{B} / \mathrm{T}$ was primarily due to vehicle emissions. To further analyze this, a daily correlation between toluene (solvent indicator) and $\mathrm{NO}_{\mathrm{x}}$ (traffic emission indicator) was calculated (using SPSS 15.0) and is shown in Fig. 8. Apparently, the correlation $(r)$ from 19 July to 3 August was low $(r<0.22)$, while after 4 August, the correlations increased dramatically. This difference was tested by a two-tailed t-test (SPSS 15.0) and showed $p<0.01$. This result lends support to our hypothesis. Apparently, painting 
Table 5. Correlations coefficients $(r)$ between $\mathrm{BC}$ and $\mathrm{PM}_{1}$ surface area $\left(\mathrm{S}\left(\mathrm{PM}_{1}\right)\right)$ and gaseous pollutants measured pre-Olympics $(18 \mathrm{July}-8$ August), and during Olympics and Paralympics (8 August-19 September).

\begin{tabular}{llrrrrrr}
\hline & & Benzene & Toluene & $\mathrm{X}+\mathrm{E}$ & $\mathrm{NO}_{\mathrm{x}}$ & $\mathrm{CO}$ & $\mathrm{SO}_{2}$ \\
\hline Pre- & $\mathrm{BC}$ & 0.19 & 0.13 & 0.10 & $0.27^{*}$ & $0.41^{* *}$ & $0.91^{* *}$ \\
8 August & $\mathrm{S}\left(\mathrm{PM}_{1}\right)$ & $0.23^{*}$ & 0.16 & 0.11 & $0.31^{*}$ & $0.33^{*}$ & $0.86^{* *}$ \\
8 August- & $\mathrm{BC}$ & $0.59^{* *}$ & $0.56^{* *}$ & $0.52^{* *}$ & $0.60^{* *}$ & $0.66^{* *}$ & $0.52^{* *}$ \\
19 September & $\mathrm{S}\left(\mathrm{PM}_{1}\right)$ & $0.60^{* *}$ & $0.59^{* *}$ & $0.57^{* *}$ & $0.64^{* *}$ & $0.63^{* *}$ & $0.32^{*}$ \\
\hline
\end{tabular}

* Correlation is significant at the 0.05 level (2-tailed).

** Correlation is significant at the 0.01 level (2-tailed).

Table 6. Comparisons of benzene/toluene ratio (B/T) from present study and previous references.

\begin{tabular}{lllll}
\hline B/T ratio & Location & Year & References & Method \\
\hline $0.60 \pm 0.20$ & Beijing & 2001 & Barletta et al. & Roadside, GC-FID/MS \\
0.58 & Beijing, PKU site & 2007 & Song et al. & Station, GC-FID/MS \\
$0.49-0.55$ & Beijing, the Fourth Ring Road & 2007 & Wei et al. & Roadside, GC-MS \\
$0.48 \pm 0.07$ & Beijing, the Fourth Ring Road & 2008 & This study & Mobile monitoring, PTR-MS \\
\hline
\end{tabular}

solvents contributed more to the low B/T level from 19 July to 3 August.

Previous studies have examined traffic-related BTEX behavior in the city of Beijing (Barletta et al., 2005; Song et al., 2007; Wei et al., 2007), generally using roadside measurements using gas chromatograph/mass spectrometry (GCMS) or GC-flame ionization detection (GC-FID). Table 6 compares the $\mathrm{B} / \mathrm{T}$ values obtained from these studies with our data. Barletta et al. (2005) reported VOC concentrations in 43 cities of China in 2001 and defined Beijing as a "trafficrelated city" for its $\mathrm{B} / \mathrm{T}$ of $0.6 \pm 0.2$. Wei et al. (2007) found values of $0.49-0.55$, a range similar to ours, from roadside measurements along the Fourth Ring Road. A higher value was reported by Song et al. (2007) at the fixed PKU site, $100 \mathrm{~m}$ from a main road. In short, previous studies generally reported higher $\mathrm{B} / \mathrm{T}$ values than ours. These differences may be caused by several factors, including the changes in fuel mixtures to the Euro 4 standard after 1 March, 2008, versus the previous Euro 3 standard, differences between the instruments used, and that $\mathrm{B} / \mathrm{T}$ is considered to increase with increasing distance from the pollution source (Gelencser et al., 1997; Simon et al., 2004). Apparently, our mobile laboratory with PTR-MS measured vehicular exhaust at the shortest distance from its sources.

\subsection{Local emission and regional transport of $\mathrm{SO}_{2}$}

Several studies on $\mathrm{SO}_{2}$ transport around Beijing predicted that high $\mathrm{SO}_{2}$ concentrations would be trapped and accumulate when prevailing winds are from the south or southwest (Sun et al., 2006; Wang et al., 2008), accounting for nearly
$23 \%$ of the total $\mathrm{SO}_{2}$ concentration (Zhang et al., 2004). Most of these studies were based on model simulations and stationary measurements. Real-time regional observations are needed to validate these predictions.

As shown in Fig. 4, we found higher $\mathrm{SO}_{2}$ concentration on the south side of the Fourth Ring Road than in the other directions, indicating possible transport of $\mathrm{SO}_{2}$ from the south. To identify the sources accounting for the high $\mathrm{SO}_{2}$ values observed from 28 July to 4 August, the mobile laboratory was driven to the southwest of Beijing outside the Fourth Ring Road on 6 August. Prevailing winds during these measurements were from the south and southwest. As shown in Fig. 9a, the $\mathrm{SO}_{2}$ concentration in the southern section was higher than that in the northern area. An increase in $\mathrm{SO}_{2}$ concentration was observed when the mobile laboratory reached Shijingshan district (Fig. 9b) and continued along Jingkai Highway and South 6 Ring Road, where concentrations were $15 \mathrm{ppb}$. The peak value exceeded $18 \mathrm{ppb}$ on Jiangshi Highway. This maximum then dropped dramatically below $10 \mathrm{ppb}$ when we passed Shijingshan district again on the return trip to $\mathrm{PKU}$.

This trend was consistent with low frequency variations in $\mathrm{NO}_{\mathrm{x}}$ concentrations and $\mathrm{S}\left(\mathrm{PM}_{1}\right)$, indicating that they were from similar combustion sources. The spikes in $\mathrm{NO}_{\mathrm{x}}$ concentration and $\mathrm{S}\left(\mathrm{PM}_{1}\right)$ during the sampling trip reflected immediate exhaust from nearby traffic, especially at the start of the trip in the northern area, near the PKU site. Background increases with broad peaks in $\mathrm{NO}_{\mathrm{x}}$ concentrations and $\mathrm{S}\left(\mathrm{PM}_{1}\right)$ reflected local or regional transport plumes. Peak values of $\mathrm{SO}_{2}, \mathrm{NO}_{\mathrm{x}}$, and $\mathrm{S}\left(\mathrm{PM}_{1}\right)$ in Shijingshan district were likely from local industrial sources a relatively short distances from 


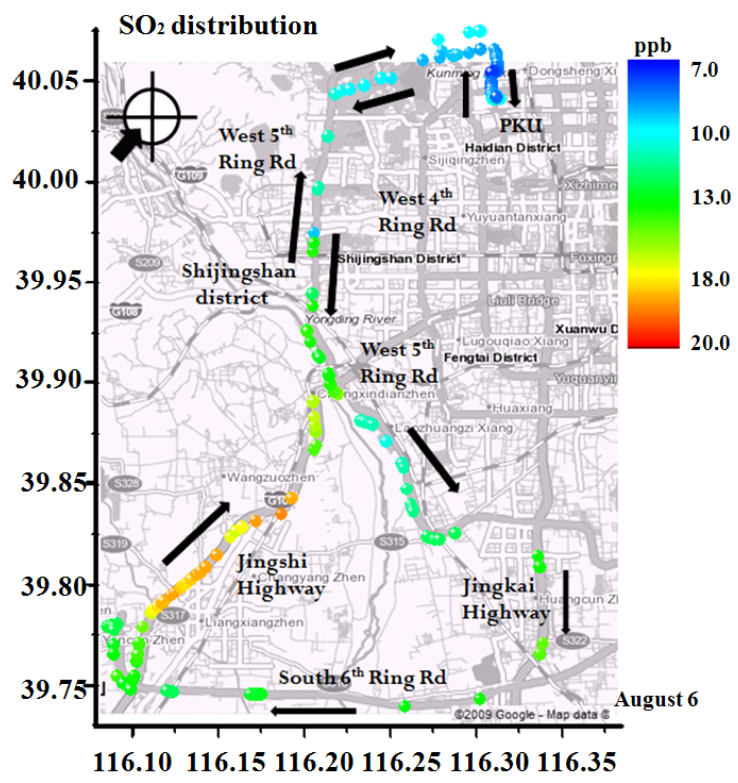

(a)

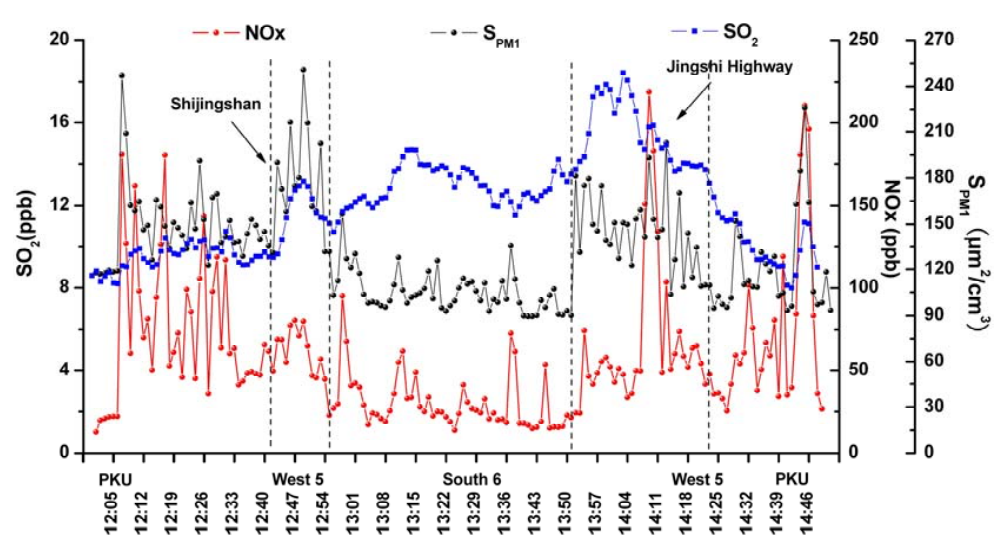

(b)

Fig. 9. $\mathrm{SO}_{2}$ spatial distribution in (a) southwest of Beijing and (b) corresponding time serials variation. The prevailing winds were shown by arrow on top left of the map in (a) and the thin arrows in (a) represented the order of the cruise. The long dashed line in (b) shows the range of local emission in Shijingshan district and regional transport in Jingshi Highway.

the road (approximately $12 \mathrm{~km}$ ). Along Jingshi Highway, the peaks likely reflected sources lying within a larger radius $(30 \mathrm{~km})$, showing the effects of regional transport.

\section{Conclusions}

This study demonstrated that the mobile laboratory was a useful tool for directly evaluating changes in on-road air pollutants along Beijing's Fourth Ring Road associated with short-term pollution controls for the Beijing 2008 Summer Olympics. The mobile laboratory collected data that could not have been obtained through currently existing and equipped stationary observation sites in the Beijing area.
We conducted repeated measurements on 31 days from 18 July to 6 October 2008, covering periods before, during, and after the Olympics pollution controls. Our results show that the emission control measures were effective in reducing onroad air pollutants.

High correlations among $\mathrm{NO}_{\mathrm{x}}, \mathrm{CO}$, and BTEX species were observed, indicating that the dominant source was gasoline exhaust from LDVs and MDVs. High correlations were also identified between $\mathrm{BC}$ and $\mathrm{PM}_{1}$ surface area, suggesting that HDV diesel exhaust was a major source when other $\mathrm{BC}$ and $\mathrm{PM}_{1}$ sources were strictly controlled during the Olympics period. Concentrations of $\mathrm{NO}_{\mathrm{x}}, \mathrm{CO}$, and BTEX deceased dramatically from extremely high values before traffic control regulations to their lowest concentrations 
during the Olympic periods. However, concentrations then increased gradually after the Olympic regulations were lifted, especially after the traffic control period, and varied consistently with LDV and MDV traffic-speed variations. No discernible declines in $\mathrm{BC}$ and $\mathrm{PM}_{1}$ surface area were observed before the Olympics, while gradual increases were shown afterward, a trend also reflected in the number of HDVs on the road.

The strong relationship of $\mathrm{BC}$ and $\mathrm{S}\left(\mathrm{PM}_{1}\right)$ with $\mathrm{SO}_{2}$ found before the Olympics (before 8 August) indicated that they had similar local emission or regional transport sources, which were later controlled. This suggestion was later demonstrated by the mobile monitoring in the southwest area outside Beijing on 6 August, when complex $\mathrm{SO}_{2}$ sources, both from local emissions and regional transport, were identified.

The $\mathrm{B} / \mathrm{T}$ ratio, regarded as a source indicator, was $0.26 \pm 0.06$ before 8 August, but $0.48 \pm 0.07$ in the period after 8 August. This difference points to the heavy use of painting solvents in Beijing before the Olympics (before $8 \mathrm{Au}$ gust) and the traffic speed and types after 8 August when pre-Olympics decorations were completed and rigorous controls were placed on solvent usage. With painting solvents becoming less important, the $\mathrm{B} / \mathrm{T}$ reached a value primarily controlled by vehicle emissions.

Thus, our mobile laboratory successfully demonstrated that the control strategies implemented by the Beijing EPB were able to effect short-term improvements in air quality. Further studies on regional sources of both $\mathrm{SO}_{2}$ and $\mathrm{PM}$ on different ring roads of Beijing City as well as areas south of Beijing are needed in the future.

Acknowledgements. This study was supported by Beijing Environmental Protection Bureau (OITC-G08026056). We would like to thank TSI Inc. for their assistance on $\mathrm{PM}_{1}$ surface area instrument support. Special thanks also to Chinese Meteorological Administration for meteorological data support. We also thank to Min Shao and Ying Liu for assistance in PTR-MS inter-comparison.

Edited by: R. Holzinger

\section{References}

Atkinson, R.: Atmospheric chemistry of VOCs and $\mathrm{NO}_{\mathrm{x}}$, Atmos. Environ., 34, 2063-2101, 2000.

Barletta, B., Meinardi, S., Rowland, F. S., Chan, C. Y., Wang, X., Zou, S. C., Chan, L. Y., and Blake, D. R.: Volatile organic compounds in 43 Chinese cities, Atmos. Environ., 39, 5979-5990, 2005.

Beauchamp, J., Wisthaler, A., Grabmer, W., Neuner, C., Weber, A., and Hansel, A.: Short-term measurements of $\mathrm{CO}, \mathrm{NO}, \mathrm{NO}_{2}$, organic at a motorway locationcompounds and $\mathrm{PM}_{10}$ in an Austrian valley, Atmos. Environ., 38, 2511-2522, 2004.

Brocco, D., Fratarcangeli, R., Lepore, L., Petricca, M., and Ventrone, I.: Determination of aromatic hydrocarbons in urban air of Rome., Atmos. Environ., 31, 557-566, 1997.
Bukowiecki, N., Dommen, J., Prevot, A. S. H., Richter, R., Weingartner, E., and Baltensperger, U.: A mobile pollutant measurement laboratory - measuring gas phase andaerosol ambient concentrations with high spatial and temporal resolution, Atmos. Environ., 36, 5569-5579, 2002.

Canagaratna, M. R., Jayne, J. T., Ghertner, D. A., Herndon, S., Shi, Q., Jimenez, J. L., Silva, P. J., Williams, P., Lanni, T., Drewnick, F., Demerjian, K., Kolb, C. E., and Worsnop, D. R.: Chase Studies of Particulate Emissions from in-use New York City Vehicles, Aerosol Sci.Tech., 38, 555-573 2004.

Chan, C. K. and Yao, X. H.: Air pollution in mega cities in China, Atmos. Environ., 42, 1-42, 2008.

de Gouw, J. A. and Warneke, C.: Measurment of volatile organic compounds in the earth's atmosphere using proton-transferreaction mass spectrometry, Mass Spectrom. Rev., 26, 223-257, 2007.

de Gouw, J. A., Goldan, P. D., Warneke, C., Kuster, W. C., Roberts, J. M., Marchewka, M., Bertman, S. B., Pszenny, A. A. P., and Keene, W. C: Validation of proton transfer reaction-mass spectrometry (PTR-MS) measurements of gas-phase organic compounds in the atmosphere during the New England Air Quality Study (NEAQS) in 2002, J. Geophys. Res., 108(D21), 4682, doi:10.1029/2003jd003863, 2003.

de Castro, B. R., Wang, L., Mihalic, J. N., Breysse, P. N., Geyh, A. S., and Buckley, T. J.: The Longitudinal Dependence of Black Carbon Concentration on Traffic Volume in an Urban Environment, J. Air Waste Manage. Assoc., 58, 928-939, 2008.

Fortner, E. C., Zheng, J., Zhang, R., Berk Knighton, W., Volkamer, R. M., Sheehy, P., Molina, L., and André, M.: Measurements of Volatile Organic Compounds Using Proton Transfer Reaction Mass Spectrometry during the MILAGRO 2006 Campaign, Atmos. Chem. Phys., 9, 467-481, 2009, http://www.atmos-chem-phys.net/9/467/2009/.

Fruin, S. A., Winer, A. M., and Rodes, C. E.: Black carbon concentrations in California vehicles and estimation of in-vehicle diesel exhaust particulate matter exposures, Atmos. Environ., 38, 4123-4133, 2004.

Gelencser, A., Siszler, K., and Hlavay, J.: Toluene-Benzene concentration ratio as a tool for characterizing the distance from vehicular emission sources., Environ. Sci. Technol., 31, 2869-2872, doi:10.1021/es970004c, 1997.

Han, J. and Hayashi, Y.: Assessment of private car stock and its environmental impacts in China from 2000 to 2020, Transport. Res. D, 13, 471-478, 2008.

Hao, J. M. and Wang, L. T. : Improving Urban Air Quality in China: Beijing Case Study, J. Air Waste Manage. Assoc., 55, 1298-1305, 2005.

Hao, J. M., Hu, J. N., and Fu, L. X.: Controlling vehicular emissions in Beijing during the last decade, Transport. Res. A, 40, 639-651, 2006.

Herndon, S. C., Jayne, J. T., Zahniser, M. S., Worsnop, D. R., Knighton, B., Alwine, E., Lamb, B. K., Zavala, M., Nelson, D. D., McManus, J. B., Shorter, J. H., Canagaratna, M. R., Onasch, T. B., and Kolb, C. E: Characterization of urban pollutant emission fluxes and ambient concentration distributions using a mobile laboratory with rapid response instrumentation, Faraday Discuss., 130, 327-339, 2005.

Hinds, W. C.., Aerosol Technology: Properties, Behavior, and Measurements of Airborne Particles, John Wiley \& Sons, Inc., New 
York, 1999.

Hoque, R. R., Khillare, P. S., Agarwal, T., Shridhar, V., and Balachandran, S.: Spatial and temporal variation of BTEX in the urban atmosphere of Delhi, India, Sci. Total Environ., 392, 3040, 2008.

Isakov, V., Touma, J. S., and Khlystov, A.: A Method of Assessing Air Toxics Concentrations in Urban Areas Using Mobile Platform Measurements, J. Air Waste Manage. Assoc., 51, 12861295, 2007.

Jiang, M., Marr, L. C., Dunlea, E. J., Herndon, S. C., Jayne, J. T., Kolb, C. E., Knighton, W. B., Rogers, T. M., Zavala, M., Molina, L. T., and Molina, M. J.: Vehicle fleet emissions of black carbon, polycyclic aromatic hydrocarbons, and other pollutants measured by a mobile laboratory in Mexico City, Atmos. Chem. Phys., 5, 3377-3387, 2005,

http://www.atmos-chem-phys.net/5/3377/2005/.

Khoder, M. I.: Ambient levels of volatile organic compounds in the atmosphere of Greater Cairo, Atmos. Environ., 41, 554-566, 2007.

Kirchstetter, T. W., Harley, R. A., Kreisberg, N. M., Stolzenburg, M. R., and Hering, S. V.: On-road measurement of fine particle and nitrogen oxide emissions from light- and heavy-duty motor vehicles, Atmos. Environ., 33, 2955-2968, 1999.

Kittelson, D. B., Watts, W. F., and Johnson, J. P.: Nanoparticle emissions on Minnesota highways, Atmos. Environ., 38, 9-19, 2004.

Kolb, C. E., Herndon, S. C., McManus, J. B., Shorter, J. H., Zahniser, M. S., Nelson, D. D., Jayne, J. T., Canagaratna, M. R., and Worsnop, D. R.: Mobile Laboratory with Rapid Response Instruments for Real-Time Measurements of Urban and Regional Trace Gas and Particulate Distributions and Emission Source Characteristics, Environ.Sci. Technol., 38, 5694-5703, 2004.

Lindinger, W., Hansel, A., and Jordan, A.: On-line monitoring of volatile organic compounds at pptv levels by means of protontransfer-reaction mass spectrometry (PTR-MS) - Medical applications, food control and environmental researchenvironmental research, Int. J. Mass Spectrom., 173, 191-241, 1998.

Liu, H., He, K. B., Wang, Q. D., Huo, H., Lents, J., Davis, N., Nikkila, N., Chen, C. H., Osses, M., and He, C. Y.: Comparison of Vehicle Activity and Emission Inventory between Beijing and Shanghai, J. Air Waste Manage. Assoc., 57, 1172-1177, 2007.

Liu, Y., Shao, M., Zhang, J., Fu, L., and Lu, S.: Distributions and source apportionment of ambient volatile organic compounds in Beijing city, China, in: Proceeding of 2nd International Conference on Environmental Concerns, Xiamen, People R China, 1215 Octomber, 2004, 1843-1860, 2005.

Na, K., Kim, Y. P., Moon, I., and Moon, K. C.: Diurnal characteristics of volatile organic compounds in the Seoul atmosphere, Atmos. Environ., 37, 733-742, 2003.

Perry, R. and Gee, I. L.: Vehicle emissions in relation to fuel composition, Sci. Total Environ., 169, 149-156, 1995.

Pirjola, L., Paasonen, P., Pfeiffer, D., Hussein, T., Hameri, K., Koskentalo, T., Virtanen, A., Ronkko, T., Keskinen, J., Pakkanen, T. A., and Hillamo, R. E.: Dispersion of particles and trace gases nearby a city highway: Mobile laboratory measurements in Finland, Atmos. Environ., 40, 867-879, 2006.

Rogers, T. M., Grimsrud, E. P., Herndon, S. C., Jayne, J. T., Kolb, C. E., Allwine, E., Westberg, H., Lamb, B. K., Zavala, M., Molina, L. T., Molina, M. J., and Knighton, W. B.: On-road measurements of volatile organiccompounds in the Mexico City metropolitan area using proton transfer reaction mass spectrometry, Int. J. Mass Spectrom., 252, 26-37, 2006.

Schnitzhofer, R., Beauchamp, J., Dunkl, J., Wisthaler, A., Weber, A., and Hansel, A.: Long-term measurements of $\mathrm{CO}, \mathrm{NO}, \mathrm{NO}_{2}$, benzene, toluene and $\mathrm{PM}_{10}$ at a motorway location in an Austrian valley, Atmos. Environ., 42, 1012-1024, 2008.

Simon, V., Baer, M., Torres, L., Olivier, S., Meybeck, M., and Della-Massa, J. P.: The impact of reduction in the benzene limit value in gasoline on airborne benzene, toluene and xylenes levels., Sci. Total Environ., 334-335, 177-183 2004.

Song, Y., Dai, W., Shao, M., Liu, Y., Lu, S. H., Kuster, W., and Goldan, P.: Comparison of receptor models for source apportionment of volatile organic compounds in Beijing, China, Environ. Pollut., 156, 174-183, 2008.

Song, Y., Shao, M., Liu, Y., Lu, S. H., Kuster, W., Goldan, P., and Xie, S. D.: Source Apportionment of Ambient Volatile Organic Compounds in Beijing, Environ. Sci. Technol, 41, 4348-4353, 2007.

Streets, D. G., Fu, J. S., Jang, C. J., Hao, J. M., He, K. B., Tang, X. Y., Zhang, Y. H., Wang, Z. F., Li, Z. P., Zhang, Q., Wang, L. T., Wang, B. Y., and Yu, C.: Air quality during the 2008 Beijing Olympic Games, Atmos. Environ., 41, 480-492, 2007.

Sun, Y., Wang, Y. S., Liu, G. R., An, J. L., Ma, Z. Q., Shi, L. Q., and $\mathrm{Xu}, \mathrm{H}$. H.: Analysis for vertical profile of atmospheric $\mathrm{SO}_{2}$ during air seriously polluted days in Beijing, Environ. Sci., 27, 408-414, 2006 (Chinese with abstract in English).

Tang, X.: The characteristics of urban air pollution in China. Urbanization, Energy, and Air Pollution in China, edited by: Fritz, J. J. Washington, DC, The National Academies Press, 47-54, 2004.

The 14th control strategy on Beijing air quality: http://www.bjepb. gov.cn/bjhb/tabid/68/InfoID/15395/frtid/40/Default.aspx, 2008.

Wang, S. L., Xie, P. H., Hu, S. X., Wei, H. L., Hu, H. L., Xie, J., Cao, K. F., and Fang, X.: Measurement of Atmospheric Boundary Layer Pollutants by Mobile Lidar in Beijing, Environ. Sci., 29, 562-568, 2008 (Chinese with abstract in English).

Wei, S. F., Teng, M., Fu, Q., and Zhang, Y.: Pollution Characteristic and Source Analysis of BTEX in Ambient Air of Olympic Gymnasium before and after Traffic Restriction, Environmental Monitoring in China, 23, 48-52, 2007 (Chinese with Abstract in English).

Weijers, E. P., Khlystov, A. Y., Kos, G. P. A., and Erisman, J. W.: Variability of particulate matter concentrations along roads and motorways determined by a moving measurement unit, Atmos. Environ., 38, 2993-3002, 2004.

Westerdahl, D., Fruin, S., Sax, T., Fine, P. M., and Sioutas, C.: Mobile platform measurements of ultrafine particles andassociated pollutant concentrations on freeways and residential streets in Los Angeles, Atmos. Environ., 39, 3597-3610, 2005.

Westerdahl, D., Wang, X., Pan, X. C., and Zhang, K. M.: Characterization of on-road vehicle emission factors and microenvironmental air quality in Beijing, China, Atmos. Environ., 43, 697705, 2009.

Yao, X. H., Lau, N. T., Chan, C. K., and Fang. M.: Size distributions and condensation growth of submicron particles in on-road vehicle plumes in Hong Kong, Atmos. Environ., 41, 3328-3338, 2007.

Yao, X. H., Lau, N. T., Fang, M., and Chan, C. K.: On the timeaveraging of ultrafine particle number size spectra in vehicular plumes, Atmos. Chem. Phys., 6, 4801-4807, 2006, 
http://www.atmos-chem-phys.net/6/4801/2006/.

Zavala, M., Herndon, S. C., Slott, R. S., Dunlea, E. J., Marr, L. C., Shorter, J. H., Zahniser, M., Knighton, W. B., Rogers, T. M., Kolb, C. E., Molina, L. T., and Molina, M. J.: Characterization of on-road vehicle emissions in the Mexico City Metropolitan Area using a mobile laboratory in chase and fleet average measurement modes during the MCMA-2003 field campaign, Atmos. Chem. Phys., 6, 5129-5142, 2006,

http://www.atmos-chem-phys.net/6/5129/2006/.
Zhang, Z. G., Gao, Q. X., Han, X. Q., and Zheng, X. J.: The Study of Pollutant Transport between the Cities in North China, Research of Envrion. Sci., 17, 14-20, 2004 (Chinese with abstract in English). 